\title{
Costa Rica: Staff Report for the Second Review Under the Stand-By Arrangement; Press Release on the Executive Board Discussion; and Statement by the Executive Director for Costa Rica
}

In the context of the Second Review Under the Stand-By Arrangement, the following documents have been released and are included in this package:

- $\quad$ The staff report for the Second Review Under the Stand-By Arrangement was prepared by a staff team of the IMF, following discussions with the officials of Costa Rica that ended on November 10, 2009. Based on information available at the time of these discussions, the staff report was completed on November 30, 2009. The views expressed in the staff report are those of the staff team and do not necessarily reflect the views of the Executive Board of the IMF.

- $\quad$ A press release summarizing the views of the Executive Board as expressed during its December 16, 2009 discussion of the staff report that approved the Second Review Under the Stand-By Arrangement.

- A statement by the Executive Director for Costa Rica.

The documents listed below have been separately released

Letter of Intent sent to the IMF by the authorities of Costa Rica*

Supplement to the Memorandum of Economic and Financial Policies by the authorities of Costa Rica*

*Also included in the Staff Report

The policy of publication of staff reports and other documents allows for the deletion of marketsensitive information.

Copies of this report are available to the public from

International Monetary Fund • Publication Services

$70019^{\text {th }}$ Street, N.W. • Washington, D.C. 20431

Telephone: (202) 623-7430 • Telefax: (202) 623-7201

E-mail: publications@imf.org • Internet: http://www.imf.org

\section{International Monetary Fund Washington, D.C.}




\title{
INTERNATIONAL MONETARY FUND
}

COSTA RICA

\section{Second Review Under the Stand-By Arrangement}

\author{
Prepared by the Western Hemisphere Department
}

(In consultation with other departments)

Approved by Miguel A. Savastano (WHD) and Dominique Desruelle (SPR)

November 30, 2009

\section{EXECUTIVE SUMMARY}

- Costa Rica's economy is slowly emerging from recession. Economic activity is expanding but a number of key sectors (commerce, construction, and tourism-related industries) are still lagging. Inflation has fallen to historically low levels; there have been no balance of payments pressures; and the financial sector remains stable.

- Performance under the Stand-By Arrangement (SBA) has remained very strong. All quantitative performance criteria for end-September were met, most with considerable margins. The authorities have continued to treat the SBA as precautionary.

- The outlook for a gradual recovery amid domestic and external stability remains the central scenario. Real GDP growth is expected to rise to 2.3 percent in 2010, following a 1.5 percent contraction in 2009. Inflation is on track to fall to 5 percent (12-month basis) by end-2009 and remain within the central bank's target band of 4-6 percent in 2010 .

- Program risks have declined further and now appear broadly balanced. The main threat to the growth outlook is the possibility of a slower-than-expected global recovery. Weak revenue performance remains a risk to the program.

- The scope for further policy easing is limited. The program provides room for further fiscal stimulus in early 2010, followed by moderate withdrawal to keep financing needs in check. Upside risks to the inflation outlook suggest that the authorities should continue to maintain a cautious approach to monetary easing.

- The reduced uncertainty about the external environment and lower program risks justify modification of the frequency of program reviews from quarterly to biannual. With this modification, the third (and final) program review would take place in June 2010. 


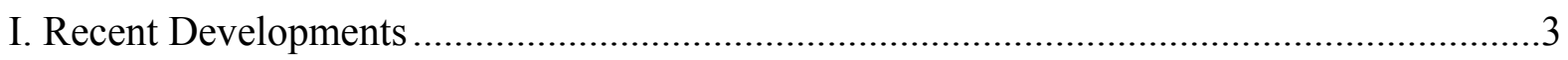

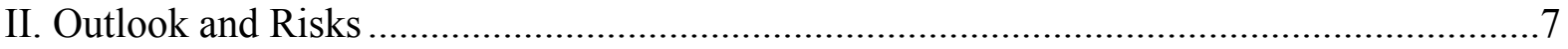

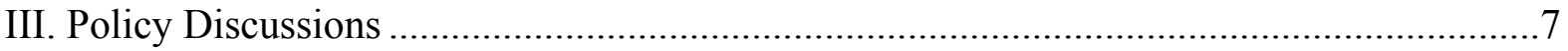

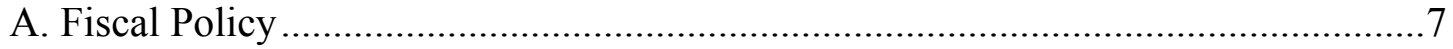

B. Monetary, Exchange Rate, and Financial Sector Policies..................................... 9

C. Program Modalities ...................................................................................... 10

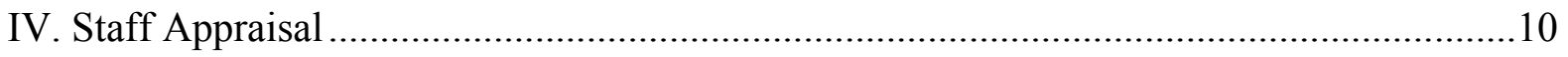

Tables

1. Quantitative Performance Measures .................................................................... 12

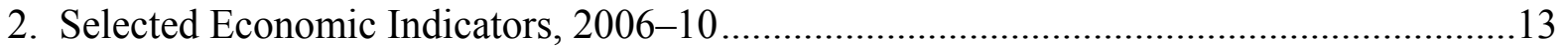

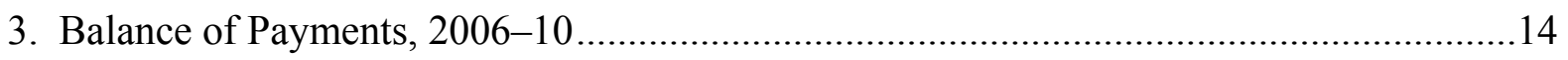

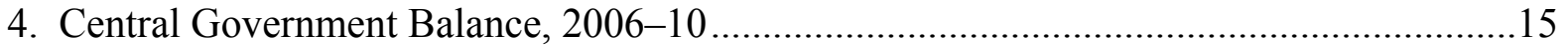

5. Central Government Balance, 2006-10 .....................................................................16

6. Combined Public Sector Operations, 2006-10 ........................................................ 17

7. Combined Public Sector Operations, 2006-10 ........................................................... 18

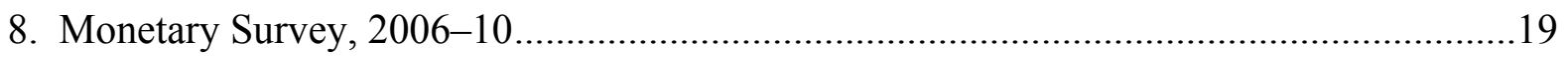

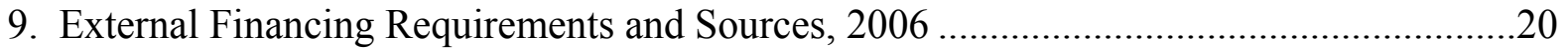

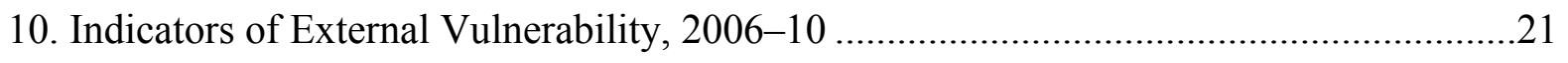

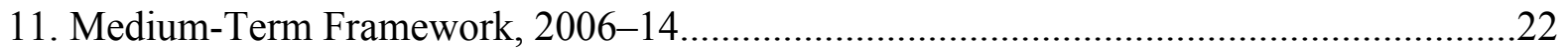

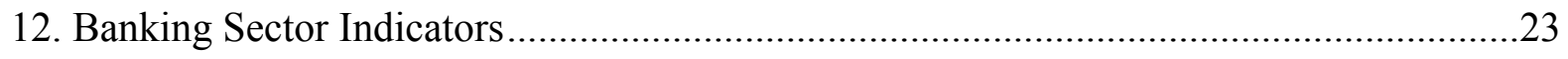

Figure

1. Recent Economic Developments ..............................................................................

Box

1. Factors Behind the Sharp Fall in Tax Revenue ................................................................

Attachments

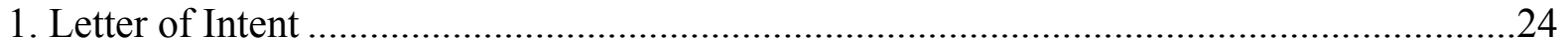

2. Supplement to the Memorandum of Economic and Financial Policies .............................26 


\section{RECENT DEVELOPMENTS ${ }^{l}$}

1. Developments since the first program review were in line with the outlook discussed in IMF Country Report No. 09/303. The recovery of Costa Rica's economy is gradually taking hold (Figure 1). In the second quarter of 2009, the decline in real GDP slowed to 2.4 percent $(\mathrm{y} / \mathrm{y})$, and in the third quarter the indicator of economic activity (IMAE) rose 1 percent (q/q, seasonally adjusted). However, the recovery has been largely driven by manufacturing, while other sectors (commerce, construction, and tourism-related industries) remain depressed. Headline and core inflation continued to fall in October, to 4.0 and 5.7 percent (12-month basis), respectively, while median annual inflation expectations declined to 7.3 percent, approaching the ceiling of the central bank's

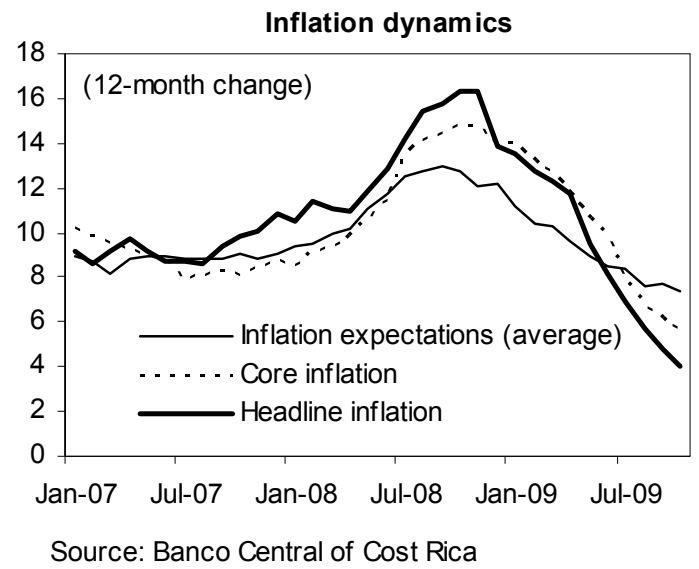
inflation target range for 2010 .

2. Although the slow recovery has continued to weigh on government revenues, the fiscal deficit has been below the program limits. Revenues of the central government through September were 7.7 percent lower than during the same period of 2008, mainly owing to a sharp drop in import-related taxes, including sales and excise taxes collected at customs (Box 1). During the same period, the central government's noninterest spending rose strongly (23.6 percent) but remained below the levels assumed in the program (owing partly to lower-than-projected inflation and a slower pace of hiring). As a result, the deficit of the central government in the first nine months of the year was below program projections (by 0.3 percent of GDP). Interest rates on domestic debt have fallen by more than 200 bps since September (to about 9.9 percent for 3-year benchmark bonds), partly as a result of a reduced volume of issuances.

3. Monetary conditions have begun to ease. Market interest rates did not fall in tandem with the July cut in the policy interest rate. However, during October market interest rates ("tasa pasiva") fell by 250 bps and have since remained on a downward trend. The real effective exchange rate (REER) continued to depreciate during the third quarter, largely due to the fall in inflation. Since mid-August, the colón has remained continuously below the

\footnotetext{
${ }^{1}$ Discussions on the second program review were held in San José during November 2-11, 2009. The staff team comprised A. Bauer (Head), M. Nozaki (all WHD), and O. Melander (SPR), and was joined by J. Gramajo (OED) and F. Delgado (Regional Resident Representative) in some meetings. The mission met with Finance Minister Phillips, Central Bank Governor Gutiérrez, other senior officials, representatives of the financial sector, and the economic teams of the leading presidential candidates. The staff team overlapped with an MCM technical assistance mission on the financial sector safety net.
} 
ceiling of the currency band. Bank credit to the private sector remained anemic, growing by less than 1.5 percent during JanuarySeptember. Banks continued to repay external credit lines and strengthened their net foreign asset positions. Solvency and credit quality indicators of the banking system deteriorated slightly in the third quarter, but remain at comfortable levels.

\section{There have not been significant}

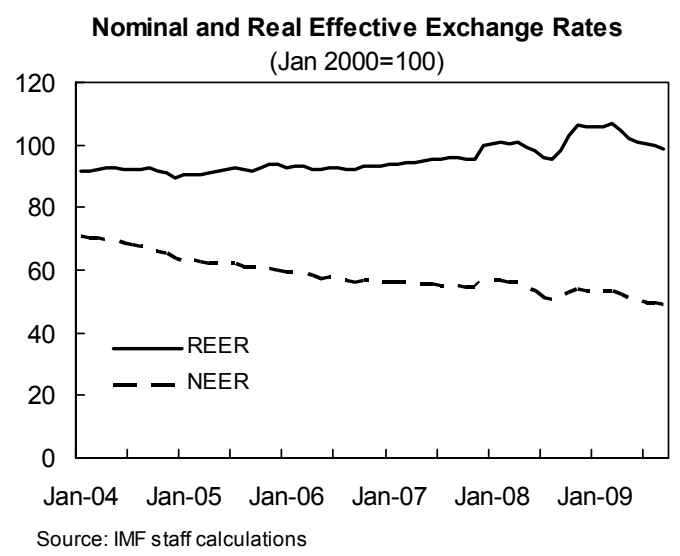

balance of payments pressures. In the first half of 2009, imports collapsed and exports experienced a significant contraction. As a result, the external current account deficit turned into broad balance, while the capital account posted a modest surplus ( 0.4 percent of GDP), despite a significant slowdown in FDI. In the third quarter, exports started to recover while import growth remained subdued. As a result, as of end-September the trade deficit was substantially lower than in 2008. Net international reserves as of mid-November stood at about $\$ 4$ billion, roughly the same amount as of end2008 (excluding the additional SDR allocation).

\section{Performance under the Stand-By Arrangement (SBA) has continued to be strong}

(Table 1). All quantitative performance criteria for end-September were met, most with considerable margins. Base money growth at end-September was somewhat above program projections, reflecting a temporary spike in commercial bank deposits at the central bank, which was subsequently reversed.

\section{Unemployment and indicators of poverty and income inequality worsened as a} result of the economic downturn. The annual household survey shows that the unemployment rate rose from 4.9 percent to 7.8 percent and the share of poor households from 17.7 percent to 18.5 percent from mid-2008 to mid-2009. Income distribution also worsened, with the income share of the lowest quintile falling by $1 / 2$ of a percentage point. The deterioration in these indicators was less severe than anticipated, partly as a result of the fall in inflation and higher government transfers. Public sector hiring (mainly police officers and teachers) also mitigated the increase in the unemployment rate.

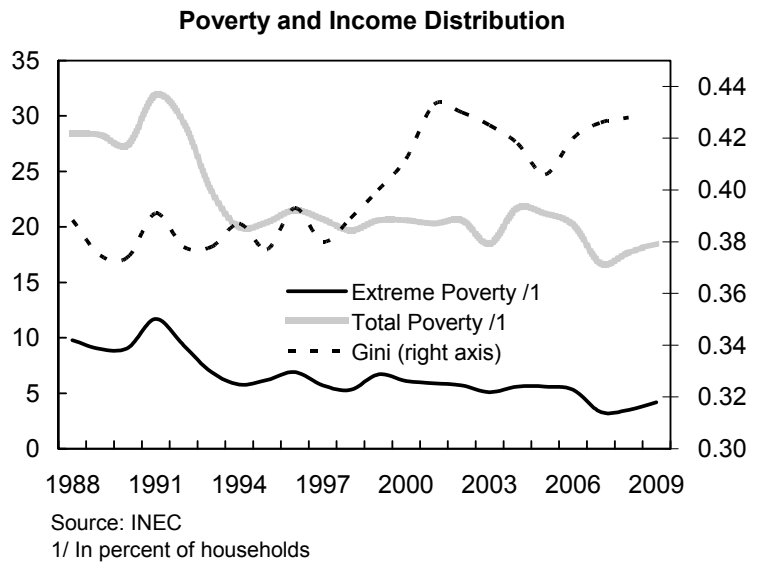




\section{Parliamentary discussions of a number of important economic laws have been}

protracted. The Assembly passed the supplementary budget for 2009 in October. However, no progress was made in approving pending legislation on central bank recapitalization, consolidated financial sector supervision, and a budget support loan from the World Bank (for $\$ 500$ million). The proximity of the general elections (February 2010) does not bode well for their approval before mid-2010.

\section{Box 1. Factors Behind the Sharp Fall in Tax Revenue}

The sharp decline in tax revenues in 2009 is mostly attributable to import-related taxes (import duties and sales and consumption taxes collected at customs). In the first nine months of the year, import-related taxes were 30 percent lower than in the same period of 2008.

About two-thirds of the decline in import-related tax revenue is explained by a lower tax base, as the value of imports in colones (excluding free trade zones and petroleum) declined by 22 percent through September. The rest is explained by a decline in the implicit effective tax rate, caused by the sharp contraction of certain imported goods that are highly taxed.

Imports of durable goods, for example, fell by 38 percent during January-September. Since cars and domestic electrical appliances are subject to above-average import tariffs and excise tax rates, the lower durable goods imports led to a more-than-proportional decline in tax revenues. The negative impact on revenues was magnified by the fact that the general sales tax is levied on the import price including tariffs and excise taxes. Revenues from car imports alone were down by 0.5 percent of GDP in the first nine months of the year, compared to the same period of 2008. In addition, the authorities estimate that the implementation of CAFTADR has reduced import duties by about 0.2 percent of GDP.
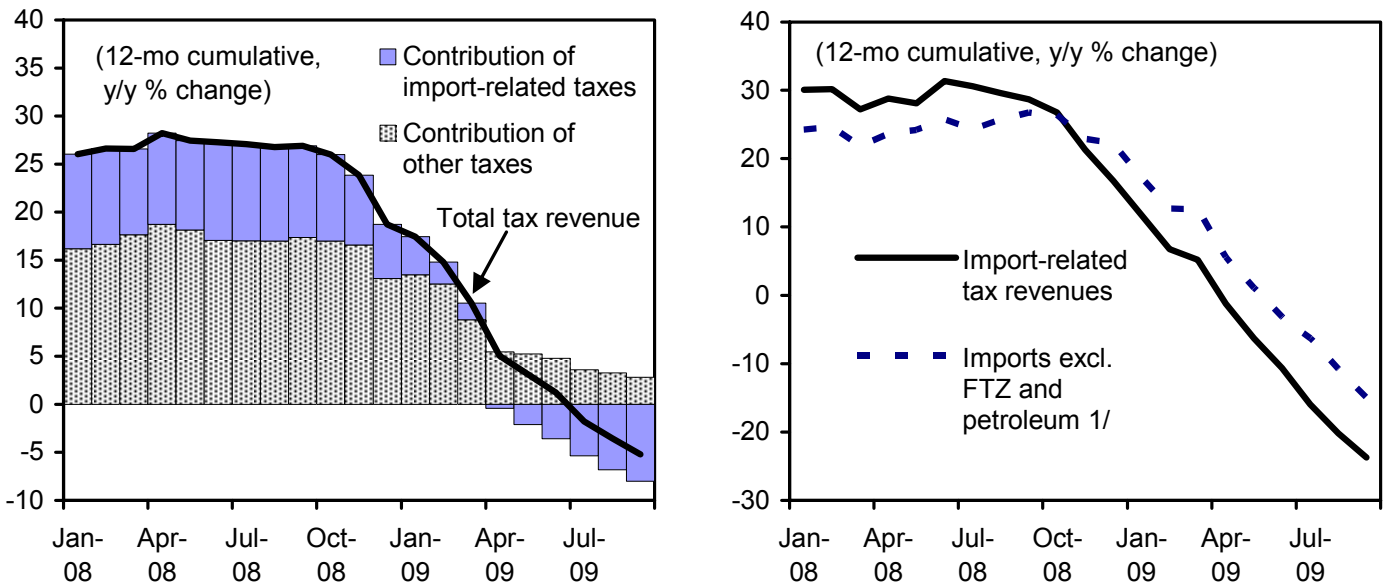

Sources: Costa Rican authorities; and Fund staff calculations. $1 / \ln$ Colones. 
Figure 1. Costa Rica: Recent Economic Developments

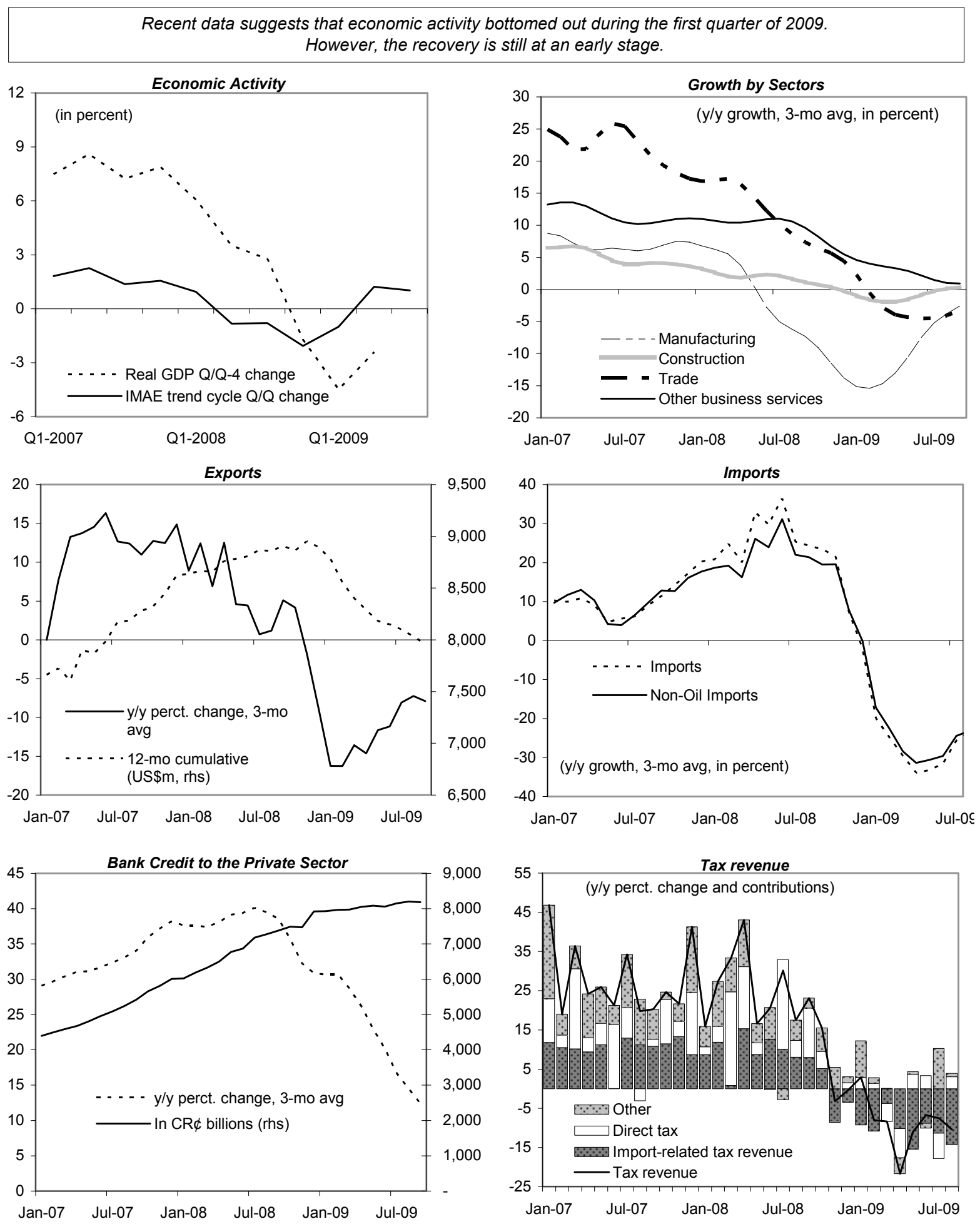

Sources: Country authorities; and Fund staff calculations. 


\section{OUTLOOK AND RISKS}

\section{The economic outlook has not changed significantly since the first program}

review. ${ }^{2}$ The central scenario continues to assume a gradual recovery with real GDP growing by 2.3 percent in 2010 . Annual inflation is on track to fall to 5 percent by end-2009, and remain within the central bank's target band of 4-6 percent in 2010. In view of the continued import contraction and strength of services exports, the external current account deficits in 2009 and 2010 are projected to be somewhat lower than previously envisaged ( 3 percent and 4.5 percent of GDP, respectively).

9. Risks to the outlook have declined further and now appear broadly balanced. A slower-than-expected recovery of Costa Rica's main trading partners presents the main risk to growth. However, there are also some upside risks given the recent opening of the telecommunications and insurance sectors to private operators, which could attract additional foreign direct investment. Short-term risks to the balance of payments have moderated with the recent strengthening of the colón, the revised outlook for the current account deficit, and the seasonal pick up of foreign exchange inflows expected by year-end. Weak revenue performance remains the main risk to the program, as it could lead to higher-than-projected fiscal deficits and domestic financing requirements.

\section{Policy Discussions}

10. There was agreement that the $S B A$ continues to provide a sound framework to bolster confidence and support the recovery. Policy discussions focused on the size and phasing of fiscal stimulus in 2010, the appropriate monetary policy stance, the next steps in the transition to greater exchange rate flexibility and inflation targeting, and the health of the financial sector. The authorities reiterated their intention to continue treating the SBA as precautionary.

\section{A. Fiscal Policy}

11. The fiscal deficit targets agreed during the first review were maintained, despite the lower-than-projected revenues. The targets were seen as continuing to strike a reasonable balance between the goals of supporting domestic demand and containing the increase in government borrowing and public debt. Compared to the projections in IMF Country Report No. 09/303, the revised program contemplates 0.3 percent of GDP of lower tax revenues in 2009. A slower pace of execution of budgeted spending (including public investment) is expected to offset the lower revenues and allow to comply with the end-year deficit targets for the central government and the combined public sector (4.1 percent of GDP and 4.8 percent of GDP, respectively) without additional policy measures. Total revenue and expenditure projections for 2010 were adjusted for the lower level of revenues and

\footnotetext{
${ }^{2}$ See IMF Country Report No. 09/303, pp. 7-8
} 
expenditures now projected for 2009; the deficit targets for the central government and the combined public sector, however, remain the same as those agreed during the first review (4.1 percent of GDP and 4.7 percent of GDP, respectively).

Costa Rica: Central Government Balance in 2009-10

\begin{tabular}{|c|c|c|c|c|c|c|c|c|c|c|c|c|c|c|c|c|}
\hline & \multicolumn{2}{|c|}{2009 Q1-Q3 } & \multicolumn{2}{|c|}{2009 Q4 } & \multicolumn{2}{|c|}{2009} & \multicolumn{2}{|c|}{2010} & \multicolumn{2}{|c|}{2009 Q1-Q3 } & \multicolumn{2}{|c|}{ 2009Q4 } & \multicolumn{2}{|c|}{2009} & \multicolumn{2}{|c|}{2010} \\
\hline & Prog. 1/ & Prel. & Prog. 1/ & Proj. & Prog. 1/ & Proj. & Prog. 1/ & Proj. & Prog. 1/ & Prel. & Prog. 1/ & Proj. & Prog. 1/ & Proj. & Prog. 1/ & Proj. \\
\hline & \multicolumn{8}{|c|}{ (In billions of colones) } & \multicolumn{8}{|c|}{ (In percent of GDP) } \\
\hline Revenue & 1,724 & 1,674 & 708 & 703 & 2,432 & 2,376 & 2,764 & 2,724 & 10.3 & 10.0 & 4.2 & 4.2 & 14.5 & 14.2 & 15.2 & 15.0 \\
\hline Expenditure & 2,175 & 2,081 & 937 & 975 & 3,112 & 3,057 & 3,517 & 3,477 & 13.0 & 12.4 & 5.6 & 5.8 & 18.6 & 18.2 & 19.4 & 19.1 \\
\hline Overall balance & -452 & -408 & -229 & -273 & -680 & -680 & -753 & -753 & -2.7 & -2.4 & -1.4 & -1.6 & -4.1 & -4.1 & -4.1 & -4.1 \\
\hline $\begin{array}{l}\text { Memorandum item: } \\
\text { Nominal GDP } \\
\text { (in billions of colones) }\end{array}$ & $\ldots$ & $\ldots$ & $\ldots$ & $\ldots$ & $\ldots$ & $\ldots$ & $\ldots$ & $\ldots$ & 16,754 & 16,754 & 16,754 & 16,754 & 16,754 & 16,754 & 18,175 & 18,175 \\
\hline
\end{tabular}
1/ IMF Country Report No. 09/303.

\section{The fiscal program for 2010 contemplates some backloaded withdrawal of fiscal}

stimulus. To allow more time for the recovery of private demand, the program provides for a positive fiscal impulse in the early part of the year and a withdrawal of stimulus in the latter part. There was agreement on the desirability of relying on external financing to cover a significant share of the government's borrowing needs in 2010. However, the authorities noted that this strategy would hinge on obtaining parliamentary approval for external borrowing (including the US\$500 million budget support loan from the World Bank that has already been submitted to the Assembly). If approval of external borrowing was not forthcoming, the authorities would continue to meet their financing needs in the domestic market.

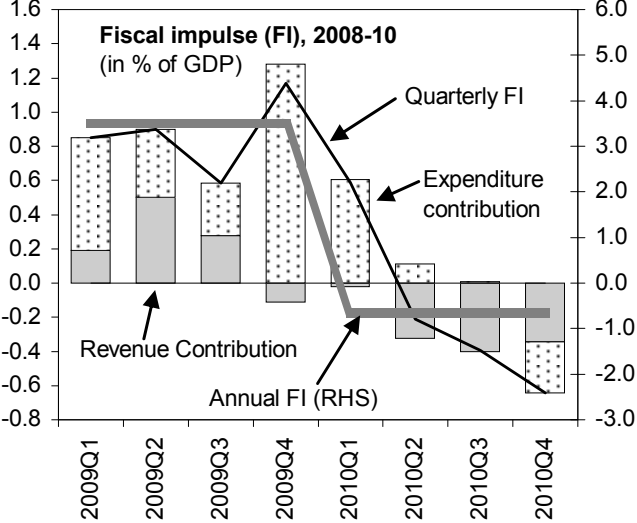

Source: IMF staff calculations. 


\section{B. Monetary, Exchange Rate, and Financial Sector Policies}

\section{There was agreement that a cautious easing bias for monetary policy remained}

appropriate in the near term. The continued downward trend of core inflation and inflation expectations, and the presence of a negative output gap bode well for compliance with the inflation target for 2010 (4-6 percent) with the present stance. The stickiness of inflation and depreciation expectations (currently around 7 percent) and the fact that the dampening effects of the fall in commodity prices of early 2009 will not recur, however, represent upside risks. ${ }^{3}$ Staff noted that the recent rise of the real policy rate had increased the scope for policy maneuver, but stressed that more aggressive interest rate easing should await firmer evidence of lower inflation (and depreciation) expectations.

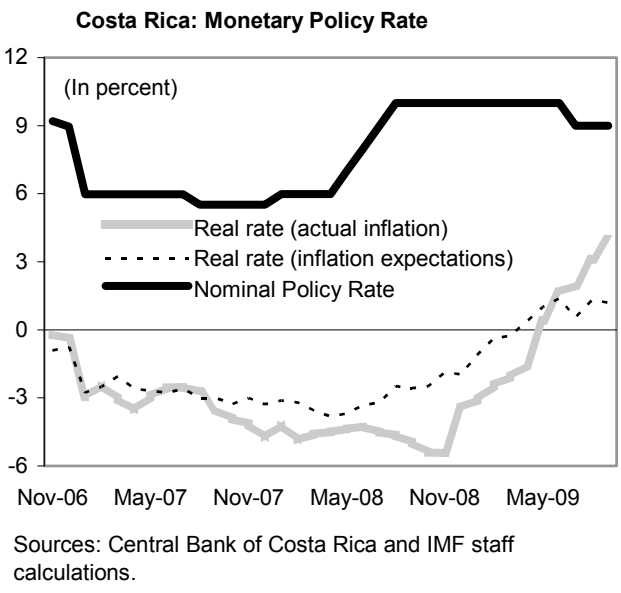

14. The authorities reiterated their intention to complete the transition toward greater exchange rate flexibility and inflation targeting by end-2010. ${ }^{4}$ They felt that the recent fluctuation of the colón away from the ceiling of the currency band and the decline in inflation provided favorable conditions for advancing further in this direction. In particular, the authorities intended to maintain the annual rate of crawl for the ceiling of the currency band at 9 percent and review regulations for foreign currency derivatives to speed the development of domestic hedging instruments. The mission suggested to also seize the opportunity to re-introduce a negative rate of crawl for the floor of the currency band, and reiterated the advice from the 2009 Article IV consultation regarding the need to clarify the central bank's role in the foreign exchange market and improve monetary operations. While they concurred with the latter recommendations, the authorities saw a strong case for maintaining the current horizontal floor for the exchange rate band as they were concerned that too many changes in the parameters could unsettle expectations.

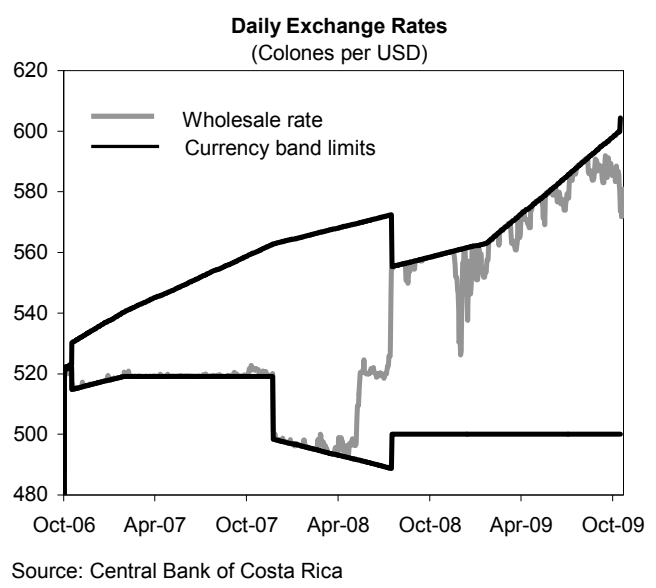

\footnotetext{
${ }^{3}$ Inflation and depreciation expectations are measured by the central bank through a monthly survey.

${ }^{4}$ The exchange rate regime of Costa Rica is classified in the category of "other managed" arrangements in the current IMF classification.
} 


\section{There was agreement that the financial sector had weathered the downturn} relatively well and that continued vigilance remained appropriate. The authorities and financial sector representatives expressed satisfaction about the resilience of the quality of credit portfolios. As of end-September 2009, the banking system's nonperforming loan ratio stood at 2.1 percent, about one percentage point higher than one year earlier. Nonperforming loans were expected to continue rising, albeit at a moderate rate. The mission found that the authorities are on track to fulfill the end-December structural benchmarks on submitting legislation to create a limited deposit insurance scheme and strengthen the bank resolution framework. A first draft of the law has been prepared and is currently under revision.

\section{Program Modalities}

\section{Considering the lower uncertainty about the external environment and the lower} program risks, it was agreed to modify the frequency of program reviews from quarterly to biannual. The program would maintain quantitative performance criteria and indicative targets for end-December 2009 and end-March 2010. The main consequence of the proposed modification would be to eliminate the review originally scheduled for late March 2010 and have the next (and final) program review in late June 2010. In addition, the availability date of the fourth purchase would be moved forward, to January 29, 2010 (Tables 1-3 in the attached Memorandum of Economic and Financial Policies). ${ }^{5}$ The mission welcomed the progress made by the authorities in implementing recommendations of the recent safeguards assessment. The central bank has hired an external auditor to conduct annual audits of its financial statements from 2008 onwards, and to prepare an analysis of existing gaps between the central bank's accounting practices and international financial reporting standards (IFRS).

\section{Staff Appraisal}

17. The Costa Rican economy is showing clearer signs of recovery. Economic activity has been growing for several months on a seasonally adjusted basis, even though this expansion is not yet broad-based. Inflation has moderated to a historically low level, there have been no balance of payments pressures, and the financial sector remains stable. These developments are broadly consistent with the staff's projections at the time of the first program review in September.

\footnotetext{
${ }^{5}$ The Technical Memorandum of Understandings (TMU) remains unchanged from the first review (IMF Country Report No. 09/303).
} 
18. Performance under the precautionary $S B A$ with the Fund has continued to be very strong, as the authorities met all quantitative performance criteria for end-September. Immediate risks to the program have declined further, especially the likelihood of balance of payments and exchange rate pressures. Weak revenue performance remains a risk, as it could lead to higher-than-projected fiscal deficits and domestic financing requirements.

\section{Fiscal policy should continue to strike a balance between supporting domestic} demand and keeping government borrowing in check. In the first three quarters of 2009, fiscal policy has provided timely support to domestic demand, despite a somewhat slower than projected execution of public spending. The program for 2010 provides room for some additional fiscal stimulus in the early part of the year, to allow more time for private demand to recover.

20. A gradual easing bias for monetary policy remains adequate for the near term. Recent inflation and exchange rate developments have increased the room for policy maneuver, but there remain upside risks to the inflation outlook that warrant maintaining a cautious approach to monetary easing. Staff welcomes the authorities' commitment to advance in the transition toward inflation targeting and greater exchange rate flexibility. It encourages them to seize the opportunity to clarify the central bank's role in the foreign exchange market and improve the framework to conduct monetary operations, in line with the staff's recommendations of the recent 2009 Article IV consultation.

21. While progress is being made on some structural reforms, the continued delay in parliamentary approval of a number of important economic laws is disappointing. Good progress is being made toward the submission of legislation to create a limited deposit insurance and strengthen the bank resolution framework (end-December structural benchmarks under the program), and the authorities are implementing key recommendations of the safeguards assessment. Staff reiterates the importance of approving legislation on central bank recapitalization, consolidated financial sector supervision, and foreign financing for the 2010 budget.

22. Staff recommends the approval of the second review under the $S B A$. Performance under the program has been strong, and the authorities' policies continue to be adequate to support economic recovery while maintaining internal and external stability. 
Table 1. Costa Rica: Quantitative Performance Measures

(In billion of colones, unless otherwise indicated)

\begin{tabular}{|c|c|c|c|c|c|c|c|c|c|}
\hline & \multicolumn{8}{|c|}{2009 Program } & \multirow{3}{*}{$\frac{2010 \text { Program }}{\frac{\text { End-March 2/ }}{\text { Proposed }}}$} \\
\hline & \multicolumn{2}{|c|}{ End-March 1/ } & \multicolumn{2}{|c|}{ End-June } & \multicolumn{2}{|c|}{ End-September } & \multicolumn{2}{|c|}{ End-December } & \\
\hline & Prog. 3/ & Actual & Prog. 3/ & Actual & Prog. 4/ & Actual & Prog. 4/ & $\overline{\text { posed }}$ & \\
\hline \multicolumn{10}{|l|}{ Quantitative Performance Criteria } \\
\hline Floor on cash balance of the Central Government (cumulative) & -210 & -106 & -312 & -206 & -471 & -377 & -639 & -639 & -322 \\
\hline Ceiling on the debt stock of the Central Government & 4,303 & 4,239 & 4,356 & 4,338 & 4,753 & 4,551 & 4,871 & 4,914 & 5,286 \\
\hline Ceiling on NDA of the Central Bank $5 /$ & -915 & $-1,301$ & -786 & $-1,244$ & -970 & $-1,170$ & -896 & -896 & -800 \\
\hline Floor on NIR of the Central Bank (million of US\$) 5 / & 3,500 & 4,167 & 3,350 & 3,936 & 3,555 & 4,059 & 3,705 & 3,705 & 3,405 \\
\hline \multicolumn{10}{|l|}{ Continuous Performance Criteria } \\
\hline Accumulation of external debt arrears & 0 & 0 & 0 & 0 & & 0 & & 0 & 0 \\
\hline \multicolumn{10}{|l|}{ Indicative targets } \\
\hline Floor on cash balance of the combined public sector (cumulative) & -146 & -43 & -325 & -179 & -524 & -411 & -774 & -774 & -352 \\
\hline \multicolumn{10}{|l|}{ Memorandum item } \\
\hline Base money & 1,102 & 1,101 & 1,144 & 1,024 & 1,079 & 1,170 & 1,240 & 1,240 & 1,163 \\
\hline Program exchange rate (ask price, colones per U.S. dollar) & 576 & 558 & 576 & 569 & 576 & 576 & 576 & 576 & 576 \\
\hline
\end{tabular}

Sources: Central Bank of Costa Rica; Ministry of Finance; and Fund staff projections.

1/ Projection only. Performance criteria were only set from end-June onward.

2/ The end-March 2010 quantitative PCs will be evaluated at the 2009 program exchange rates as defined in the TMU for the first review (IMF Country Report No. 09/303).

3/ IMF Country Report No. 09/134.

4/ IMF Country Report No. 09/303.

$5 /$ The floor on NIR and ceiling on NDA at end-September and end-December have been adjusted by $\$ 205$ million compared to the levels set at program approval (IMF Country Report No. 09/134) to reflect the special and general SDRs allocations of 132.81 millions SDRs. 
Table 2. Costa Rica: Selected Economic Indicators 2006-10

$\begin{array}{lr}\text { Per capita income (2008, U.S. dollars) } & 6,544 \\ \text { Population (July 2008, millions) } & 4.5 \\ \text { Life expectancy (2005, years) } & 79.1\end{array}$

Unemployment (2009, percent of labor force) $\quad 7.8$

Poverty (2009, percent of households) $\quad 18.5$

Extreme poverty (2009, percent of households) $\quad 4.2$

\begin{tabular}{llllll}
\hline & 2006 & 2007 & 2008 & 2009 & 2010 \\
\cline { 3 - 4 } & & & Prog. 1/ Proj. & Prog. 1/ Proj. \\
\hline
\end{tabular}

National Income and Prices

GDP at constant prices

Implicit deflator

Consumer prices (end of period)

\section{External Sector}

Exports of goods (volume, fob)

Imports of goods (volume, cif)

Terms of trade (deterioration -)

Real Effective Exchange Rate (eop; depreciation -)

Money and Credit

Base money

Broad money

Bank credit to private sector

Lending interest rate (end of period)

Public Finances

Combined public sector primary balance $2 /$

Combined public sector overall balance $2 /$

Central government balance

Social security balance

Central bank balance

Other public enterprises and entities balance

Combined public sector debt (gross) 2/

Of which: External public debt $3 /$

(Annual percentage change, unless otherwise indicated)

$\begin{array}{rrrrrrr}8.8 & 7.8 & 2.6 & -1.5 & -1.5 & 2.3 & 2.3 \\ 11.0 & 9.3 & 12.1 & 8.9 & 8.9 & 6.0 & 6.0 \\ 9.4 & 10.8 & 13.9 & 5.0 & 5.0 & 5.0 & 5.0 \\ & & & & & & \\ 10.6 & 9.2 & -3.4 & -6.9 & -8.2 & 2.5 & 3.1 \\ 9.3 & 4.1 & 5.8 & -12.3 & -17.8 & 3.1 & 7.5 \\ -3.9 & -3.7 & -4.6 & 5.2 & 4.9 & -2.3 & -1.8 \\ 0.9 & 2.8 & 5.4 & \ldots & \ldots & \ldots & \ldots \\ & & & & & & \\ 26.9 & 33.0 & 11.9 & 7.7 & 7.7 & 10.0 & 9.7 \\ 25.3 & 16.3 & 17.3 & 15.6 & 16.2 & 12.8 & 13.0 \\ 28.5 & 38.3 & 31.8 & 4.7 & 5.6 & 12.7 & 13.1 \\ 20.7 & 16.3 & 20.7 & \ldots & \ldots & \ldots & \ldots\end{array}$

(In percent of GDP)

Savings and Investment

Gross domestic investment

Gross national savings

2.8

4.1

2.3

$-2.4$

$-2.5$

$-4.8$

$-2.3$

$-4.1$

$-2.3$

$\begin{array}{ll}-1.4 & 0.3\end{array}$

$-0.3$

$-4.1$

$-4.1$

$-4.1$

0.6

0.2

0.2

0.1
-0.6

$-4.1$

$-1.1$

$-0.7$

$-0.2$

$-0.8$

$-0.8$

0.0

0.4
43.2

0.0

$-0.1$

$-0.1$

0.0

$-0.6$

9.4

7.8

5.5

39.9

39.9

41.6

0.0

41.6

$26.4 \quad 24.6$

$$
25.8
$$

18.3

16.6

17.1

5.5

9.3

6.7

External Sector

Trade balance

Current account balance

Foreign direct investment

\begin{tabular}{|c|c|c|c|c|c|c|}
\hline-12.1 & -11.4 & -16.8 & -10.2 & -8.8 & -11.3 & -11.3 \\
\hline-4.5 & -6.3 & -9.2 & -3.6 & -3.0 & -4.8 & -4 \\
\hline 6.1 & 6.2 & 6.8 & 4.3 & 4.1 & 4.7 & 4. \\
\hline
\end{tabular}

(In millions of U.S. dollars, unless otherwise indicated)

\begin{tabular}{lrrrrrrr} 
Change in net international reserves (increase -) & -802 & -839 & 315 & 0 & 0 & -100 & -100 \\
Net international reserves 4/ & 3,115 & 4,114 & 3,799 & 4,004 & 4,004 & 4,104 & 4,104 \\
-in months of nonmaquila imports of G\&S & 3.5 & 3.8 & 4.3 & 4.1 & 4.2 & 4.0 & 4.0 \\
Gross Domestic Product & 22,528 & 26,269 & 29,664 & 29,291 & 29,291 & 30,433 & 30,429 \\
\hline
\end{tabular}

Sources: Central Bank of Costa Rica; Ministry of Finance; and Fund staff projections.

1/ IMF Country Report No. 09/303.

2/ Combined Public sector $=$ Central government + Central bank + Other public enterprises and entities (excluding ICE).

3/ The revision from IMF Country Report No. 09/303 reflects an application of the residency criterion to measure external debt.

4 / Includes valuation adjustments of US $\$ 160$ million in 2007 for reclassification of capital contribution to FLAR and US\$205 million in 2009 for SDR allocation. 
Table 3. Costa Rica: Balance of Payments 2006-10

(In millions of U.S. dollars, unless otherwise indicated)

\begin{tabular}{|c|c|c|c|c|c|c|c|}
\hline & \multirow[t]{2}{*}{2006} & \multirow[t]{2}{*}{2007} & \multirow[t]{2}{*}{2008} & \multicolumn{2}{|c|}{2009} & \multicolumn{2}{|c|}{2010} \\
\hline & & & & Prog. 1/ & Proj. & Prog. 1/ & Proj. \\
\hline Current Account & $-1,023$ & $-1,646$ & $-2,732$ & $-1,057$ & -890 & $-1,474$ & $-1,384$ \\
\hline Trade balance & $-2,727$ & $-2,985$ & $-4,984$ & $-2,979$ & $-2,589$ & $-3,439$ & $-3,437$ \\
\hline Trade balance goods for processing & 1,210 & 2,214 & 1,859 & 2,175 & 2,463 & 2,239 & 2,199 \\
\hline Export of goods (f.o.b.) & 8,102 & 9,299 & 9,566 & 8,798 & 8,694 & 9,132 & 9,120 \\
\hline General merchandise and others & 3,370 & 3,802 & 4,339 & 3,859 & 3,768 & 4,044 & 4,064 \\
\hline Goods for processing & 4,732 & 5,498 & 5,227 & 4,939 & 4,925 & 5,088 & 5,056 \\
\hline Import of goods (f.o.b.) & 10,829 & 12,285 & 14,551 & 11,777 & 11,283 & 12,571 & 12,557 \\
\hline General merchandise and others & 7,306 & 9,001 & 11,183 & 9,012 & 8,820 & 9,721 & 9,700 \\
\hline Oil products & 1,250 & 1,444 & 2,089 & 1,254 & 1,224 & 1,571 & 1,621 \\
\hline Others & 6,057 & 7,557 & 9,094 & 7,758 & 7,596 & 8,151 & 8,079 \\
\hline Goods for processing & 3,522 & 3,284 & 3,368 & 2,765 & 2,463 & 2,849 & 2,857 \\
\hline Services & 1,351 & 1,734 & 2,201 & 2,002 & 2,246 & 2,118 & 2,340 \\
\hline Of which: Travel & 1,222 & 1,393 & 1,692 & 1,442 & 1,492 & 1,554 & 1,558 \\
\hline Income & 4 & -865 & -391 & -491 & -877 & -517 & -636 \\
\hline Of which: Interest on external public debt & -160 & -177 & -180 & -191 & -180 & -175 & -191 \\
\hline Of which: FDI income, net & -113 & -998 & -442 & -450 & -812 & -605 & -605 \\
\hline Current transfers & 349 & 470 & 442 & 411 & 330 & 364 & 350 \\
\hline Financial and Capital Account & 1,675 & 2,315 & 2,413 & 1,057 & 890 & 1,574 & 1,484 \\
\hline Direct investment & 1,371 & 1,634 & 2,015 & 1,270 & 1,201 & 1,420 & 1,295 \\
\hline Capital flows & 303 & 660 & 391 & -213 & -311 & 154 & 189 \\
\hline Public sector & -164 & 0 & 11 & 104 & 89 & 457 & 454 \\
\hline Disbursements & 199 & 236 & 737 & 577 & 547 & 673 & 655 \\
\hline Amortization (inc. changes in PE deposits) & -363 & -237 & -726 & -473 & -458 & -216 & -200 \\
\hline Private net capital & 467 & 660 & 380 & -317 & -401 & -303 & -265 \\
\hline Of which: Commercial banks & 66 & 830 & 159 & -711 & -873 & 0 & 0 \\
\hline Of which: Private nonfinancial sector & 401 & -170 & 221 & 393 & 473 & -303 & -265 \\
\hline Errors and Omissions & 150 & 171 & 4 & 0 & 0 & 0 & 0 \\
\hline \multirow[t]{2}{*}{ Change in Net Reserves (increase -) } & -802 & -839 & 315 & 0 & 0 & -100 & -100 \\
\hline & \multicolumn{7}{|c|}{ (Annual percentage change) } \\
\hline \multicolumn{8}{|l|}{ Export of Goods (f.o.b.) } \\
\hline Value & 14.1 & 14.8 & 2.9 & -8.0 & -9.1 & 3.8 & 4.9 \\
\hline Volume & 10.6 & 9.2 & -3.4 & -6.9 & -8.2 & 2.5 & 3.1 \\
\hline \multicolumn{8}{|l|}{ Import of Goods (c.i.f.) } \\
\hline Value & 16.0 & 12.7 & 18.1 & -18.4 & -22.4 & 5.9 & 12.5 \\
\hline Volume & 9.3 & 4.1 & 5.8 & -12.3 & -17.8 & 3.1 & 7.5 \\
\hline \multicolumn{8}{|l|}{ Of which: oil } \\
\hline Value & 25.2 & 15.6 & 44.7 & -40.0 & -41.4 & 25.3 & 32.4 \\
\hline Volume & 8.7 & 4.6 & 2.6 & -8.8 & -4.9 & 8.2 & 5.6 \\
\hline & \multicolumn{7}{|c|}{ (In percent of GDP) } \\
\hline Current account & -4.5 & -6.3 & -9.2 & -3.6 & -3.0 & -4.8 & -4.5 \\
\hline Non-oil current account & 1.0 & -0.8 & -2.2 & 0.7 & 1.1 & 0.3 & 0.8 \\
\hline Export of goods (f.o.b.) & 36.0 & 35.4 & 32.2 & 30.0 & 29.7 & 30.0 & 30.0 \\
\hline Import of goods (f.o.b.) & 48.1 & 46.8 & 49.1 & 40.2 & 38.5 & 41.3 & 41.3 \\
\hline Non-oil goods imports (f.o.b.) & 42.5 & 41.3 & 42.0 & 35.9 & 34.3 & 36.1 & 35.9 \\
\hline Income & 0.0 & -3.3 & -1.3 & -1.7 & -3.0 & -1.7 & -2.1 \\
\hline Direct investment & 6.1 & 6.2 & 6.8 & 4.3 & 4.1 & 4.7 & 4.3 \\
\hline \multicolumn{8}{|l|}{ Memorandum Items: } \\
\hline Net international reserves (US\$ million) 2/ & 3,115 & 4,114 & 3,799 & 4,004 & 4,004 & 4,104 & 4,104 \\
\hline -in months of non-maquila imports & 3.5 & 3.8 & 4.3 & 4.1 & 4.2 & 4.0 & 4.0 \\
\hline -in percent short-term debt $3 /$ & 109.7 & 97.0 & 79.6 & 104.2 & 104.9 & 100.2 & 103.2 \\
\hline External debt $4 /$ & 31.0 & 31.8 & 31.2 & 31.3 & 30.4 & 30.3 & 29.9 \\
\hline
\end{tabular}

Sources: Central Bank of Costa Rica; and Fund staff estimates.

$1 /$ IMF Country Report No. 09/303.

2 / Includes valuation adjustments of US $\$ 160$ million in 2007 for reclassification of capital contribution to FLAR and US\$205 million in 2009 for new SDR allocation.

$3 /$ Public and private sector external debt on remaining maturity. Includes trade credits.

$4 /$ Includes public and private sector debt. 
Table 4. Costa Rica: Central Government Balance 2006-10

(In percent of GDP)

\begin{tabular}{|c|c|c|c|c|c|c|c|}
\hline & \multirow[t]{2}{*}{2006} & \multirow[t]{2}{*}{2007} & \multirow[t]{2}{*}{2008} & \multicolumn{2}{|c|}{2009} & \multicolumn{2}{|c|}{2010} \\
\hline & & & & Prog. 1/ & Proj. & Prog. 1/ & Proj. \\
\hline Revenue & 14.2 & 15.5 & 15.9 & 14.5 & 14.2 & 15.2 & 15.0 \\
\hline Tax revenue & 14.0 & 15.2 & 15.7 & 14.3 & 13.9 & 14.9 & 14.7 \\
\hline Direct taxes & 4.0 & 4.6 & 5.1 & 4.6 & 4.7 & 5.1 & 5.1 \\
\hline Sales tax & 5.4 & 5.9 & 6.0 & 5.4 & 5.0 & 5.5 & 5.3 \\
\hline Excise, customs, and others & 4.5 & 4.8 & 4.6 & 4.2 & 4.3 & 4.3 & 4.3 \\
\hline Nontax revenue & 0.2 & 0.3 & 0.2 & 0.3 & 0.3 & 0.3 & 0.3 \\
\hline Expenditure & 15.7 & 15.2 & 16.2 & 18.6 & 18.2 & 19.4 & 19.1 \\
\hline Current noninterest & 10.5 & 10.5 & 11.4 & 13.9 & 13.8 & 14.4 & 14.3 \\
\hline Wages and salaries & 4.6 & 4.4 & 4.6 & 5.8 & 5.8 & 6.0 & 6.0 \\
\hline Pensions and social security & 2.4 & 2.4 & 2.4 & 2.7 & 2.7 & 2.7 & 2.7 \\
\hline Transfers and other & 3.4 & 3.7 & 4.4 & 5.5 & 5.4 & 5.7 & 5.6 \\
\hline Interest & 4.2 & 3.3 & 2.7 & 2.6 & 2.4 & 2.9 & 2.9 \\
\hline o/w adjustment for TUDES 2/ & 0.4 & 0.3 & 0.5 & 0.2 & 0.2 & 0.3 & 0.3 \\
\hline Capital & 1.0 & 1.3 & 1.8 & 2.1 & 2.0 & 2.1 & 2.0 \\
\hline Recapitalization of commercial bank & 0.0 & 0.0 & 0.4 & 0.0 & 0.0 & 0.0 & 0.0 \\
\hline Primary balance & 2.7 & 3.7 & 2.4 & -1.5 & -1.6 & -1.2 & -1.2 \\
\hline Structural primary balance 3/ & 2.4 & 2.7 & 2.0 & -1.3 & -1.5 & -0.8 & -0.8 \\
\hline Overall Balance & -1.4 & 0.3 & -0.3 & -4.1 & -4.1 & -4.1 & -4.1 \\
\hline Structural overall balance 3/ & -1.8 & -0.6 & -0.6 & -3.9 & -3.9 & -3.7 & -3.7 \\
\hline Total Financing & 1.4 & -0.3 & 0.3 & 4.1 & 4.1 & 4.1 & 4.1 \\
\hline External (net) & -0.1 & 0.3 & -1.2 & -0.6 & 0.0 & 1.5 & 1.5 \\
\hline Internal (net) & 1.5 & -0.6 & 1.5 & 4.7 & 4.0 & 2.7 & 2.7 \\
\hline \multicolumn{8}{|l|}{ Memorandum Items: } \\
\hline Central government debt & 33.3 & 27.6 & 24.9 & 28.9 & 28.9 & 31.0 & 31.0 \\
\hline External 4/ & 6.7 & 5.7 & 4.3 & 7.1 & 4.3 & 8.2 & 5.6 \\
\hline Domestic & 26.7 & 21.9 & 20.6 & 21.8 & 24.6 & 22.8 & 25.4 \\
\hline
\end{tabular}

Sources: Ministry of Finance; and Fund staff estimates.

1/ IMF Country Report No. 09/303.

2/ TUDES are inflation indexed bonds of the central government. The inflation adjustment of principal is not reflected as interest expenditure in the fiscal accounts of the Costa Rican authorities, but is added here to the Fund presentation of the fiscal deficit and public sector debt.

3/ For 2008, excludes one time expense for recapitalization of public commercial banks.

4/ The revision from IMF Country Report No. 09/303 reflects an application of the residency criterion to measure external debt. 
Table 5. Costa Rica: Central Government Balance 2006-10

(In billions of colones)

\begin{tabular}{|c|c|c|c|c|c|c|c|}
\hline & \multirow[t]{2}{*}{2006} & \multirow[t]{2}{*}{2007} & \multirow[t]{2}{*}{2008} & \multicolumn{2}{|c|}{2009} & \multicolumn{2}{|c|}{2010} \\
\hline & & & & Prog. 1/ & Proj. & Prog. 1/ & Proj. \\
\hline Revenue & 1,639 & 2,105 & 2,490 & 2,432 & 2,376 & 2,764 & 2,724 \\
\hline Tax Revenue & 1,612 & 2,067 & 2,453 & 2,389 & 2,333 & 2,713 & 2,673 \\
\hline Direct taxes & 465 & 622 & 801 & 774 & 786 & 936 & 936 \\
\hline Sales tax & 627 & 798 & 937 & 906 & 835 & 1,000 & 960 \\
\hline Excise, customs, and others & 520 & 647 & 715 & 709 & 712 & 778 & 778 \\
\hline Nontax Revenue & 27 & 38 & 37 & 43 & 44 & 51 & 51 \\
\hline Expenditure & 1,804 & 2,062 & 2,535 & 3,112 & 3,057 & 3,517 & 3,477 \\
\hline Current noninterest & 1,212 & 1,427 & 1,776 & 2,335 & 2,320 & 2,610 & 2,590 \\
\hline Wages and salaries & 535 & 601 & 721 & 965 & 968 & 1,090 & 1,090 \\
\hline Pensions and social security & 282 & 324 & 372 & 448 & 448 & 488 & 488 \\
\hline Transfers and other & 396 & 503 & 683 & 922 & 903 & 1,032 & 1,012 \\
\hline Interest & 482 & 454 & 415 & 432 & 408 & 527 & 527 \\
\hline Of which: adjustment for TUDES : & 45 & 35 & 75 & 41 & 41 & 60 & 60 \\
\hline Capital & 110 & 180 & 279 & 345 & 329 & 381 & 360 \\
\hline Recapitalization of commercial bank & 0 & 0 & 65 & 0 & 0 & 0 & 0 \\
\hline Primary balance & 316 & 497 & 370 & -248 & -272 & -226 & -226 \\
\hline Structural primary balance $3 /$ & 274 & 370 & 320 & -219 & -243 & -143 & -144 \\
\hline Overall Balance & -165 & 43 & -45 & -680 & -680 & -753 & -753 \\
\hline Structural overall balance 3/ & -207 & -84 & -95 & -651 & -651 & -670 & -671 \\
\hline Total Financing & 165 & -43 & 45 & 680 & 680 & 753 & 753 \\
\hline External (net) & -11 & 38 & -183 & -109 & 7 & 264 & 268 \\
\hline Internal (net) & 176 & -81 & 228 & 789 & 673 & 489 & 485 \\
\hline \multicolumn{8}{|l|}{ Memorandum Items: } \\
\hline Central government debt & 3,837 & 3,744 & 3,885 & 4,843 & 4,843 & 5,631 & 5,631 \\
\hline External 4/ & 766 & 773 & 669 & 1,183 & 716 & 1,485 & 1,009 \\
\hline Domestic & 3,071 & 2,971 & 3,216 & 3,660 & 4,127 & 4,146 & 4,622 \\
\hline
\end{tabular}

Sources: Ministry of Finance; and Fund staff estimates.

1/ IMF Country Report No. 09/303.

2/ TUDES are inflation indexed bonds of the central government. The inflation adjustment of principal is not reflected as interest expenditure in the fiscal accounts of the Costa Rican authorities, but is added here to the IMF presentation of the fiscal deficit and public sector debt.

3/ For 2008, excludes one time expense for recapitalization of public commercial banks.

4/ The revision from IMF Country Report No. 09/303 reflects an application of the residency criterion to measure external debt. 
Table 6. Costa Rica: Combined Public Sector Operations 2006-10 1/

(In percent of GDP)

\begin{tabular}{|c|c|c|c|c|c|c|c|}
\hline & \multirow[t]{2}{*}{2006} & \multirow[t]{2}{*}{2007} & \multirow[t]{2}{*}{2008} & \multicolumn{2}{|c|}{2009} & \multicolumn{2}{|c|}{2010} \\
\hline & & & & Prog. 2/ & Proj. & Prog. 2/ & Proj. \\
\hline Revenues & 21.2 & 22.8 & 23.3 & 22.2 & 21.9 & 23.3 & 23.1 \\
\hline Tax revenue & 14.0 & 15.2 & 15.7 & 14.3 & 13.9 & 14.9 & 14.7 \\
\hline Direct taxes & 4.0 & 4.6 & 5.1 & 4.6 & 4.7 & 5.1 & 5.1 \\
\hline Sales tax & 5.4 & 5.9 & 6.0 & 5.4 & 5.0 & 5.5 & 5.3 \\
\hline Excise, customs, and others & 4.5 & 4.8 & 4.6 & 4.2 & 4.3 & 4.3 & 4.3 \\
\hline Nontax revenue & 0.2 & 0.3 & 0.2 & 0.3 & 0.3 & 0.3 & 0.3 \\
\hline Contributions to social security & 6.2 & 6.3 & 6.8 & 7.1 & 7.1 & 7.5 & 7.5 \\
\hline Operating balance of public enterprises & 0.7 & 1.0 & 0.6 & 0.6 & 0.6 & 0.6 & 0.6 \\
\hline Noninterest expenditure & 18.4 & 18.8 & 21.0 & 24.6 & 24.4 & 25.6 & 25.4 \\
\hline Wages and salaries & 7.2 & 7.1 & 7.5 & 8.9 & 9.0 & 9.4 & 9.4 \\
\hline Goods and services & 1.8 & 2.0 & 2.1 & 2.4 & 2.3 & 2.5 & 2.4 \\
\hline Pensions & 4.4 & 4.4 & 4.6 & 5.2 & 5.2 & 5.6 & 5.6 \\
\hline Transfers & 2.9 & 3.2 & 3.8 & 4.7 & 4.7 & 4.9 & 4.8 \\
\hline Central Bank primary losses & 0.2 & 0.0 & -0.2 & 0.0 & 0.0 & 0.1 & 0.1 \\
\hline Net capital expenditure & 1.9 & 2.1 & 3.2 & 3.3 & 3.2 & 3.2 & 3.1 \\
\hline Central Government (incl. capital transfers) & 1.0 & 1.3 & 2.2 & 2.1 & 2.0 & 2.1 & 2.0 \\
\hline Rest of the Nonfinancial Public Sector & 0.9 & 0.8 & 1.0 & 1.3 & 1.3 & 1.1 & 1.1 \\
\hline Primary balance & 2.8 & 4.1 & 2.3 & -2.4 & -2.5 & -2.3 & -2.3 \\
\hline Net interest expenditure & 3.4 & 2.9 & 2.1 & 2.4 & 2.2 & 2.4 & 2.4 \\
\hline Overall Balance & -0.7 & 1.2 & 0.1 & -4.8 & -4.8 & -4.7 & -4.7 \\
\hline Central government & -1.4 & 0.3 & -0.3 & -4.1 & -4.1 & -4.1 & -4.1 \\
\hline of which: Adjustment for TUDES $3 /$ & -0.4 & -0.3 & -0.5 & -0.2 & -0.2 & -0.3 & -0.3 \\
\hline Social Security Agency & 1.9 & 1.2 & 0.6 & 0.2 & 0.2 & 0.1 & 0.1 \\
\hline of which : Adjus tment for TUDES $3 /$ & 0.3 & 0.3 & 0.2 & 0.1 & 0.1 & 0.1 & 0.1 \\
\hline Other public enterprises and entities & 0.0 & 0.4 & 0.0 & -0.1 & -0.1 & 0.0 & 0.0 \\
\hline Central bank & -1.1 & -0.7 & -0.2 & -0.8 & -0.8 & -0.6 & -0.6 \\
\hline Total Financing & 0.7 & -1.2 & -0.1 & 4.8 & 4.8 & 4.7 & 4.7 \\
\hline External & 0.1 & 0.3 & -1.1 & -0.3 & -0.1 & 1.6 & 1.3 \\
\hline Internal & 0.6 & -1.5 & 0.9 & 5.1 & 4.9 & 3.1 & 3.3 \\
\hline \multicolumn{8}{|l|}{ Memorandum items: } \\
\hline Total combined public sector debt & 47.8 & 43.2 & 35.8 & 39.9 & 39.9 & 41.6 & 41.6 \\
\hline External 4/ & 9.4 & 7.8 & 5.5 & 8.3 & 5.5 & 9.3 & 6.7 \\
\hline Domestic & 38.4 & 35.4 & 30.3 & 31.6 & 34.4 & 32.3 & 34.9 \\
\hline
\end{tabular}

Sources: Ministry of Finance; and Fund staff estimates.

1/ Combined Public sector $=$ Central government + Central bank + Other public enterprises and entities (excluding ICE).

2/ IMF Country Report No. 09/303.

3/ TUDES are inflation indexed bonds of the central government. The inflation adjustment of principal is not reflected as interest expenditure in the fiscal accounts of the Costa Rican authorities, but is added here to the IMF presentation of the fiscal deficit and public sector debt.

4/ The revision from IMF Country Report No. 09/303 reflects an application of the residency criterion to measure external debt. 
Table 7. Costa Rica: Combined Public Sector Operations 2006-10 1/

(In billions of colones)

\begin{tabular}{|c|c|c|c|c|c|c|c|}
\hline & \multirow[t]{2}{*}{2006} & \multirow[t]{2}{*}{2007} & \multirow[t]{2}{*}{2008} & \multicolumn{2}{|c|}{2009} & \multicolumn{2}{|c|}{2010} \\
\hline & & & & Prog. 2/ & Proj. & Prog. 2/ & Proj. \\
\hline Revenues & 2,437 & 3,098 & 3,635 & 3,718 & 3,662 & 4,243 & 4,204 \\
\hline Tax revenue & 1,612 & 2,067 & 2,453 & 2,389 & 2,333 & 2,713 & 2,673 \\
\hline Direct taxes & 465 & 622 & 801 & 774 & 786 & 936 & 936 \\
\hline Sales tax & 627 & 798 & 937 & 906 & 835 & 1,000 & 960 \\
\hline Excise, customs, and others & 520 & 647 & 715 & 709 & 712 & 778 & 778 \\
\hline Nontax revenue & 27 & 38 & 37 & 43 & 44 & 51 & 51 \\
\hline Contributions to social security & 715 & 855 & 1,057 & 1,190 & 1,190 & 1,371 & 1,371 \\
\hline Operating balance of public enterprises & 84 & 139 & 89 & 96 & 96 & 108 & 108 \\
\hline Noninterest expenditure & 2,119 & 2,547 & 3,279 & 4,120 & 4,088 & 4,658 & 4,618 \\
\hline Wages and salaries & 829 & 959 & 1,165 & 1,498 & 1,501 & 1,717 & 1,717 \\
\hline Goods and services & 211 & 266 & 321 & 404 & 392 & 449 & 439 \\
\hline Pensions & 506 & 597 & 719 & 877 & 877 & 1,011 & 1,011 \\
\hline Transfers & 340 & 430 & 596 & 787 & 781 & 888 & 878 \\
\hline Central Bank primary losses & 17 & 5 & -27 & -2 & -2 & 13 & 13 \\
\hline Net capital expenditure & 216 & 290 & 505 & 555 & 539 & 580 & 560 \\
\hline Central Government (incl. capital transfers) & 110 & 180 & 344 & 345 & 329 & 381 & 360 \\
\hline Rest of the Nonfinancial Public Sector & 106 & 110 & 161 & 210 & 210 & 200 & 200 \\
\hline Primary balance & 317 & 552 & 357 & -402 & -426 & -415 & -414 \\
\hline Net interest expenditure & 394 & 388 & 334 & 394 & 370 & 432 & 433 \\
\hline Overall Balance & -77 & 164 & 23 & -796 & -796 & -847 & -847 \\
\hline Central government & -165 & 43 & -45 & -680 & -680 & -753 & -753 \\
\hline of which : Adjustment for TUDES $3 /$ & -45 & -35 & -75 & -41 & -41 & -60 & -60 \\
\hline Social Security Agency & 218 & 160 & 101 & 36 & 36 & 10 & 10 \\
\hline of which : Adjustment for TUDES $3 /$ & 35 & 37 & 34 & 19 & 19 & 27 & 27 \\
\hline Other public enterprises and entities & 2 & 57 & -4 & -25 & -25 & 6 & 6 \\
\hline Central bank & -131 & -96 & -29 & -127 & -127 & -110 & -110 \\
\hline Total Financing & 77 & -164 & -23 & 796 & 796 & 847 & 847 \\
\hline External & 10 & 36 & -170 & -54 & -18 & 284 & 241 \\
\hline Internal & 66 & -200 & 147 & 851 & 814 & 563 & 606 \\
\hline \multicolumn{8}{|l|}{ Memorandum items: } \\
\hline Total combined public sector debt & 5,502 & 5,869 & 5,596 & 6,681 & 6,681 & 7,569 & 7,569 \\
\hline External 4/ & 1,078 & 1,063 & 861 & 1,387 & 921 & 1,698 & 1,220 \\
\hline Domestic & 4,425 & 4,806 & 4,734 & 5,293 & 5,760 & 5,871 & 6,349 \\
\hline
\end{tabular}

Sources: Ministry of Finance; and Fund staff estimates.

1/ Combined Public sector $=$ Central government + Central bank + Other public enterprises and entities (excluding ICE).

2/ IMF Country Report No. 09/303.

$3 /$ TUDES are inflation indexed bonds of the central government. The inflation adjustment of principal is not reflected as interest expenditure in the fiscal accounts of the Costa Rican authorities, but is added here to the IMF presentation of the fiscal deficit and public sector debt.

4/ The revision from IMF Country Report No. 09/303 reflects an application of the residency criterion to measure external debt. 
Table 8. Costa Rica: Monetary Survey 2006-10

(In billions of colones)

\begin{tabular}{|c|c|c|c|c|c|c|c|}
\hline & \multirow[t]{2}{*}{2006} & \multirow[t]{2}{*}{2007} & \multirow[t]{2}{*}{2008} & \multicolumn{2}{|c|}{2009} & \multicolumn{2}{|c|}{2010} \\
\hline & & & & Prog. 1/ & Proj. & Prog. 1/ & Proj. \\
\hline Net foreign assets & 1,608 & 2,125 & 2,186 & 2,475 & 2,476 & 2,630 & 2,641 \\
\hline $\begin{array}{c}\text { Net international reserves } \\
\text { (In millions of US\$) }\end{array}$ & $\begin{array}{l}1,607 \\
3,115\end{array}$ & $\begin{array}{l}2,037 \\
4,114\end{array}$ & $\begin{array}{l}2,090 \\
3,799\end{array}$ & $\begin{array}{l}2,337 \\
4,004\end{array}$ & $\begin{array}{l}2,338 \\
4,004\end{array}$ & $\begin{array}{l}2,487 \\
4,104\end{array}$ & $\begin{array}{l}2,487 \\
4,104\end{array}$ \\
\hline $\begin{array}{l}\text { Net domestic assets } \\
\text { Net domestic credit } \\
\text { Credit to the Nonfinancial Public Sector } \\
\text { Credit to Other Depository Corporations ( } r \\
\text { Credit to Other Financial Corporations (ne } \\
\text { Credit to the Private Sector (net) } \\
\text { Capital account (-) } \\
\text { Other items net (-) } \\
\text { Monetary stabilization bonds (-) }\end{array}$ & $\begin{array}{r}-834 \\
-395 \\
-43 \\
-361 \\
-1 \\
11 \\
1,138 \\
-153 \\
-1,424\end{array}$ & $\begin{array}{r}-1,097 \\
-429 \\
-61 \\
-380 \\
2 \\
10 \\
1,182 \\
-8 \\
-1,842\end{array}$ & $\begin{array}{r}-1,035 \\
-547 \\
-20 \\
-525 \\
0 \\
-2 \\
1,219 \\
-254 \\
-1,453\end{array}$ & $\begin{array}{r}-1,236 \\
-835 \\
-94 \\
-735 \\
-3 \\
-2 \\
1,336 \\
-339 \\
-1,398\end{array}$ & $\begin{array}{r}-1,236 \\
-833 \\
-92 \\
-735 \\
-3 \\
-2 \\
1,358 \\
-356 \\
-1,405\end{array}$ & $\begin{array}{r}-1,266 \\
-835 \\
16 \\
-846 \\
-3 \\
-2 \\
1,303 \\
-339 \\
-1,395\end{array}$ & $\begin{array}{r}-1,281 \\
-903 \\
-74 \\
-823 \\
-4 \\
-2 \\
1,468 \\
-492 \\
-1,355\end{array}$ \\
\hline $\begin{array}{l}\text { Monetary base } \\
\text { Currency } \\
\text { Required reserves }\end{array}$ & $\begin{array}{l}773 \\
413 \\
360\end{array}$ & $\begin{array}{r}1,028 \\
546 \\
482\end{array}$ & $\begin{array}{r}1,151 \\
575 \\
576\end{array}$ & $\begin{array}{r}1,240 \\
623 \\
616\end{array}$ & $\begin{array}{r}1,240 \\
623 \\
616\end{array}$ & $\begin{array}{r}1,364 \\
683 \\
681\end{array}$ & $\begin{array}{r}1,360 \\
662 \\
698\end{array}$ \\
\hline Net foreign assets & 67 & -347 & -473 & -87 & 8 & -90 & 8 \\
\hline $\begin{array}{l}\text { Net domestic assets } \\
\text { Net domestic credit } \\
\text { Credit to nonfinancial public sector (net) } \\
\text { Credit to the private sector } \\
\text { Credit to financial corporations (net) } \\
\text { Capital account } \\
\text { Other items (net) }\end{array}$ & $\begin{array}{r}4,980 \\
6,488 \\
541 \\
4,347 \\
1,600 \\
1,037 \\
-472\end{array}$ & $\begin{array}{r}6,250 \\
8,097 \\
338 \\
6,014 \\
1,746 \\
1,237 \\
-609\end{array}$ & $\begin{array}{r}7,796 \\
10,064 \\
316 \\
7,926 \\
1,823 \\
1,597 \\
-671\end{array}$ & $\begin{array}{r}8,732 \\
11,042 \\
559 \\
8,302 \\
2,181 \\
1,656 \\
-653\end{array}$ & $\begin{array}{r}8,739 \\
11,117 \\
506 \\
8,367 \\
2,243 \\
1,653 \\
-724\end{array}$ & $\begin{array}{r}9,977 \\
12,348 \\
682 \\
9,356 \\
2,310 \\
1,717 \\
-653\end{array}$ & $\begin{array}{r}10,080 \\
12,506 \\
626 \\
9,460 \\
2,419 \\
1,736 \\
-690\end{array}$ \\
\hline $\begin{array}{l}\text { Liabilities } \\
\text { National currency } \\
\text { Foreign currency }\end{array}$ & $\begin{array}{l}5,046 \\
2,673 \\
2,373\end{array}$ & $\begin{array}{l}5,904 \\
3,502 \\
2,402\end{array}$ & $\begin{array}{l}7,323 \\
3,950 \\
3,373\end{array}$ & $\begin{array}{l}8,645 \\
4,481 \\
4,164\end{array}$ & $\begin{array}{l}8,747 \\
4,501 \\
4,246\end{array}$ & $\begin{array}{l}9,887 \\
5,097 \\
4,790\end{array}$ & $\begin{array}{r}10,088 \\
5,121 \\
4,967\end{array}$ \\
\hline Net foreign assets & 1,674 & 1,778 & 1,713 & 2,388 & 2,484 & 2,539 & 2,649 \\
\hline $\begin{array}{l}\text { Net domestic assets } \\
\text { Net domestic credit } \\
\text { Capital account } \\
\text { Other items (net) }\end{array}$ & $\begin{array}{r}4,706 \\
4,845 \\
-101 \\
-240\end{array}$ & $\begin{array}{r}5,645 \\
6,291 \\
55 \\
-590\end{array}$ & $\begin{array}{r}6,997 \\
8,221 \\
378 \\
-847\end{array}$ & $\begin{array}{r}7,679 \\
8,766 \\
320 \\
-767\end{array}$ & $\begin{array}{r}7,640 \\
8,781 \\
295 \\
-846\end{array}$ & $\begin{array}{r}8,813 \\
10,054 \\
414 \\
-826\end{array}$ & $\begin{array}{r}8,794 \\
10,013 \\
268 \\
-951\end{array}$ \\
\hline Broad money (M4) & 6,381 & 7,423 & 8,709 & 10,067 & 10,123 & 11,353 & 11,443 \\
\hline \multicolumn{8}{|l|}{ Memorandum Items } \\
\hline Monetary base & 26.9 & 33.0 & 11.9 & 7.7 & 7.7 & 10.0 & 9.7 \\
\hline Broad money (M4) & 25.3 & 16.3 & 17.3 & 15.6 & 16.2 & 12.8 & 13.0 \\
\hline Credit to the private sector (National Currency) & 34.0 & 45.2 & 27.1 & 3.4 & 4.8 & 12.4 & 12.2 \\
\hline Credit to the Private Sector (Foreign Currency) & 22.3 & 30.0 & 38.2 & 6.5 & 6.6 & 13.0 & 14.1 \\
\hline & \multicolumn{7}{|c|}{ (In percent of GDP) } \\
\hline Monetary base & 6.7 & 7.6 & 7.4 & 7.4 & 7.4 & 7.5 & 7.5 \\
\hline Broad money (M4) & 55.4 & 54.7 & 55.8 & 60.1 & 60.4 & 62.5 & 63.0 \\
\hline Credit to the private sector (National Currency) & 20.7 & 25.5 & 28.2 & 27.1 & 27.5 & 28.1 & 28.5 \\
\hline Credit to the private sector (Foreign Currency) & 17.0 & 18.8 & 22.6 & 22.4 & 22.4 & 23.3 & 23.6 \\
\hline & \multicolumn{7}{|c|}{ (In billion of Colones) } \\
\hline Net domestic assets (Program Definition) & -833 & $-1,009$ & -939 & $-1,098$ & $-1,098$ & $-1,123$ & $-1,127$ \\
\hline
\end{tabular}

Sources: BCCR; and Fund staff estimates.

1/ IMF Country Report No. 09/303. 
Table 9. Costa Rica: External Financing Requirements and Sources 2006-10 (In millions of U.S. dollars)

\begin{tabular}{|c|c|c|c|c|c|c|c|}
\hline & \multirow[t]{2}{*}{2006} & \multirow[t]{2}{*}{2007} & \multirow[t]{2}{*}{2008} & \multicolumn{2}{|c|}{2009} & \multicolumn{2}{|c|}{2010} \\
\hline & & & & Prog. 1/ & Proj. & Prog. 1/ & Proj. \\
\hline 1. Gross Financing Requirements & 4,497 & 5,324 & 6,659 & 5,860 & 5,664 & 5,415 & 5,300 \\
\hline Current account deficit (exc. official transfers) & 1,023 & 1,646 & 2,732 & 1,057 & 890 & 1,474 & 1,384 \\
\hline Debt amortization 2/ & 2,673 & 2,838 & 4,242 & 4,803 & 4,774 & 3,841 & 3,817 \\
\hline Medium and long-term debt & 577 & 483 & 1,018 & 808 & 779 & 583 & 559 \\
\hline Public sector & 363 & 237 & 726 & 497 & 458 & 208 & 200 \\
\hline Private sector & 215 & 246 & 292 & 311 & 321 & 375 & 358 \\
\hline Short-term debt $3 /$ & 2,095 & 2,356 & 3,224 & 3,995 & 3,995 & 3,258 & 3,258 \\
\hline Repayment of arrears & 0 & 0 & 0 & 0 & 0 & 0 & 0 \\
\hline Gross reserves accumulation & 802 & 839 & -315 & 0 & 0 & 100 & 100 \\
\hline 2. Available Financing & 4,497 & 5,324 & 6,659 & 5,860 & 5,664 & 5,415 & 5,300 \\
\hline Foreign direct investment (net) & 1,371 & 1,634 & 2,015 & 1,270 & 1,201 & 1,420 & 1,295 \\
\hline Debt financing & 3,020 & 4,072 & 5,258 & 4,159 & 4,423 & 4,363 & 4,006 \\
\hline Medium and long-term financing & 664 & 848 & 1,263 & 901 & 1,165 & 1,037 & 802 \\
\hline Public sector & 199 & 236 & 737 & 577 & 547 & 673 & 655 \\
\hline Private sector & 466 & 612 & 526 & 324 & 618 & 364 & 147 \\
\hline Short-term financing & 2,356 & 3,224 & 3,995 & 3,258 & 3,258 & 3,326 & 3,204 \\
\hline Other flows 4/ & 107 & -382 & -614 & 431 & 39 & -368 & 0 \\
\hline \multicolumn{8}{|l|}{ Memorandum Item: } \\
\hline Gross financing requirement (in percent of GDP) & 20.0 & 20.3 & 22.4 & 20.0 & 19.3 & 17.8 & 17.4 \\
\hline
\end{tabular}

Sources: Authorities; and Fund staff estimates.

1/ IMF Country Report No. 09/303.

2/ Excluding the IMF.

$3 /$ Original maturity of less than 1 year. Stock at the end of the previous period.

4/ Includes all other net financial flows, and errors and omissions. 
Table 10. Costa Rica: Indicators of External Vulnerability 2006-10

\begin{tabular}{lrrrrr}
\hline & & & & \multicolumn{2}{c}{ Projection } \\
\cline { 3 - 6 } & 2006 & 2007 & 2008 & 2009 \\
\hline Merchandise exports (percent change) 1/ $1 /$ & 11.3 & 12.8 & 14.1 & -13.1 & 7.8 \\
Merchandise imports (percent change) 1/ & 15.3 & 23.2 & 24.2 & -21.1 & 10.0 \\
Terms of trade (percent change) & -3.9 & -3.7 & -4.6 & 4.9 & -1.8 \\
Current account balance (in percent of GDP) & -4.5 & -6.3 & -9.2 & -3.0 & -4.5 \\
Central bank net international reserves (in US\$ millions) & $3,114.6$ & $4,113.7$ & $3,799.1$ & $4,004.1$ & $4,104.1$ \\
-In months of next year's imports of nonmaquila goods and services & 3.5 & 3.8 & 4.3 & 4.2 & 4.0 \\
-In percent of base money & 208.6 & 199.3 & 183.3 & 190.1 & 182.8 \\
-In percent of M4 & 25.3 & 27.6 & 24.2 & 23.3 & 21.7 \\
-In percent of deposits in foreign currency & 68.0 & 85.3 & 62.6 & 55.5 & 50.1 \\
-In percent of short-term external debt 2/ & 109.7 & 97.0 & 79.6 & 104.9 & 103.2 \\
Public external debt service (in percent of GDP) & 2.0 & 1.8 & 3.1 & 2.2 & 1.3 \\
External debt (in percent of GDP) & 31.0 & 31.8 & 31.2 & 30.4 & 29.9 \\
External debt (in percent of exports) & 63.2 & 64.9 & 67.7 & 70.4 & 68.7 \\
REER appreciation (+) & 0.9 & 2.8 & 5.4 & $\ldots$ & $\ldots$ \\
\hline
\end{tabular}

Sources: Central Bank of Costa Rica; and Fund staff estimates.

$1 /$ In value terms, excludes maquila.

2/ Public and private sector external debt on remaining maturity. Includes trade credits. 
Table 11. Costa Rica: Medium-Term Framework 2006-14

(Annual percentage change; unless otherwise indicated)

\begin{tabular}{|c|c|c|c|c|c|c|c|c|c|}
\hline & \multirow[b]{2}{*}{2006} & \multirow[b]{2}{*}{2007} & \multirow[b]{2}{*}{2008} & \multicolumn{6}{|c|}{ Projection } \\
\hline & & & & 2009 & 2010 & 2011 & 2012 & 2013 & 2014 \\
\hline Real GDP & 8.8 & 7.8 & 2.6 & -1.5 & 2.3 & 3.5 & 4.5 & 5.2 & 5.2 \\
\hline Consumption & 5.4 & 6.8 & 4.3 & 2.0 & 2.3 & 2.5 & 2.9 & 4.1 & 4.1 \\
\hline Private consumption & 5.7 & 7.4 & 4.5 & 1.7 & 2.2 & 2.5 & 3.0 & 4.3 & 4.3 \\
\hline Government consumption & 2.9 & 2.2 & 2.4 & 4.0 & 3.3 & 2.6 & 2.5 & 2.4 & 2.5 \\
\hline Gross domestic investment & 13.9 & -1.3 & 12.2 & -30.0 & 11.5 & 7.7 & 9.8 & 8.7 & 8.3 \\
\hline Fixed capital formation & 10.8 & 18.0 & 11.9 & -12.0 & 3.0 & 5.8 & 6.2 & 6.3 & 6.2 \\
\hline Exports of goods and nonfactor services & 10.3 & 10.0 & -1.8 & -7.0 & 2.9 & 5.0 & 5.0 & 5.2 & 5.3 \\
\hline Imports of goods and nonfactor services & 8.1 & 4.5 & 4.3 & -16.3 & 6.7 & 5.4 & 4.9 & 5.1 & 5.2 \\
\hline Consumption (contribution to growth) & 3.9 & 4.9 & 3.1 & 1.5 & 1.7 & 1.9 & 2.2 & 3.0 & 2.9 \\
\hline Investment (contribution to growth) & 2.2 & 3.7 & 2.7 & -3.0 & 0.7 & 1.3 & 1.4 & 1.4 & 1.5 \\
\hline Inventories (contribution to growth) & 1.4 & -4.0 & 0.2 & -5.0 & 1.5 & 0.3 & 0.7 & 0.5 & 0.5 \\
\hline Net exports (contribution to growth) & 1.3 & 3.2 & -3.4 & 4.9 & -1.6 & 0.1 & 0.2 & 0.3 & 0.3 \\
\hline \multicolumn{10}{|l|}{ Investment and savings (in percent of GDP) } \\
\hline Savings & 26.4 & 24.6 & 25.8 & 14.8 & 17.8 & 19.2 & 20.7 & 21.6 & 22.3 \\
\hline National savings & 21.9 & 18.3 & 16.6 & 11.8 & 13.3 & 14.4 & 15.9 & 16.6 & 17.2 \\
\hline External savings $1 /$ & 4.5 & 6.3 & 9.2 & 3.0 & 4.5 & 4.8 & 4.9 & 5.0 & 5.1 \\
\hline Gross domestic investment & 26.4 & 24.6 & 25.8 & 14.8 & 17.8 & 19.2 & 20.7 & 21.6 & 22.3 \\
\hline Private sector & 16.8 & 18.6 & 20.2 & 16.6 & 16.8 & 17.1 & 17.4 & 17.6 & 18.0 \\
\hline Public sector & 3.1 & 3.2 & 4.0 & 4.1 & 4.1 & 4.1 & 4.2 & 4.2 & 4.3 \\
\hline Inventory changes & 6.5 & 2.8 & 1.6 & -5.9 & -3.0 & -2.0 & -0.9 & -0.3 & 0.0 \\
\hline \multicolumn{10}{|l|}{ Balance of payments (in percent of GDP) } \\
\hline Current account balance & -4.5 & -6.3 & -9.2 & -3.0 & -4.5 & -4.8 & -4.9 & -5.0 & -5.1 \\
\hline Trade balance & -12.1 & -11.4 & -16.8 & -8.8 & -11.3 & -11.9 & -12.4 & -12.9 & -13.4 \\
\hline Services & 6.0 & 6.6 & 7.4 & 7.7 & 7.7 & 8.0 & 8.2 & 8.5 & 8.9 \\
\hline Income & 0.0 & -3.3 & -1.3 & -3.0 & -2.1 & -2.0 & -1.8 & -1.7 & -1.7 \\
\hline Current transfers & 1.6 & 1.8 & 1.5 & 1.1 & 1.2 & 1.1 & 1.1 & 1.1 & 1.1 \\
\hline Financial and capital account & 7.4 & 8.7 & 8.1 & 3.0 & 4.9 & 5.5 & 5.8 & 6.0 & 6.2 \\
\hline Direct investment & 6.1 & 6.2 & 6.8 & 4.1 & 4.3 & 4.2 & 4.2 & 4.2 & 4.2 \\
\hline Capital flows & 1.3 & 2.5 & 1.3 & -1.1 & 0.6 & 1.3 & 1.6 & 1.8 & 2.0 \\
\hline Public sector & -0.7 & 0.0 & 0.0 & 0.3 & 1.5 & 0.4 & 0.3 & 0.2 & 0.3 \\
\hline Private net capital & 2.1 & 2.5 & 1.3 & -1.4 & -0.9 & 0.9 & 1.3 & 1.6 & 1.7 \\
\hline Errors and Omissions & 0.7 & 0.7 & 0.0 & 0.0 & 0.0 & 0.0 & 0.0 & 0.0 & 0.0 \\
\hline Change in Net Reserves (increase -) & -3.6 & -3.2 & 1.1 & 0.0 & -0.3 & -0.6 & -0.9 & -1.0 & -1.0 \\
\hline \multicolumn{10}{|l|}{ Memorandum items: } \\
\hline GDP deflator & 11.0 & 9.3 & 12.1 & 8.9 & 6.0 & 5.0 & 4.5 & 4.0 & 3.8 \\
\hline CPI (avg) & 11.5 & 9.4 & 13.4 & 8.4 & 5.0 & 4.7 & 4.5 & 4.5 & 4.2 \\
\hline CPI (eop) & 9.4 & 10.8 & 13.9 & 5.0 & 5.0 & 4.5 & 4.5 & 4.5 & 4.0 \\
\hline Net international reserves (millions of US\$) & 3,115 & 4,114 & 3,799 & 4,004 & 4,104 & 4,304 & 4,604 & 4,954 & 5,354 \\
\hline
\end{tabular}

Sources: Central Bank of Costa Rica; and Fund staff estimates.

1/ External current account deficit. 
Table 12. Costa Rica: Banking Sector Indicators

(In percent)

\begin{tabular}{|c|c|c|c|c|c|c|c|c|c|c|}
\hline & \multicolumn{7}{|c|}{ Total Banking system } & \multirow{3}{*}{\multicolumn{2}{|c|}{$\begin{array}{c}\begin{array}{l}\text { Public } \\
\text { banks }\end{array} \\
\frac{\text { Private }}{\text { Banks }} \\
\text { Sep }\end{array}$}} & \multirow[t]{3}{*}{$\begin{array}{l}\text { Coope- } \\
\text { ratives }\end{array}$} \\
\hline & \multicolumn{4}{|c|}{2008} & \multicolumn{3}{|c|}{2009} & & & \\
\hline & Mar & Jun & Sep & Dec & Mar & Jun & Sep & & & \\
\hline \multicolumn{11}{|l|}{ Capitalization } \\
\hline Risk-adjusted capital ratio & 15.5 & 14.7 & 14.5 & 15.1 & 15.2 & 15.4 & 15.4 & 13.8 & 13.4 & 19.1 \\
\hline Capital-to-assets ratio & 12.8 & 12.8 & 12.8 & 13.3 & 13.3 & 13.5 & 13.7 & 12.0 & 10.7 & 18.6 \\
\hline \multicolumn{11}{|l|}{ Asset quality } \\
\hline Nonperforming loans to total loans & 1.2 & 1.1 & 1.2 & 1.5 & 1.8 & 2.0 & 2.1 & 2.8 & 1.5 & 1.0 \\
\hline Non-income generating assets to total assets & 16.6 & 17.0 & 18.1 & 18.2 & 19.1 & 18.9 & 19.0 & 21.3 & 19.7 & 5.6 \\
\hline Foreclosed assets to total assets & 0.2 & 0.2 & 0.2 & 0.3 & 0.4 & 0.4 & 0.5 & 0.5 & 0.6 & 0.3 \\
\hline Loan loss provisions to total loans & 1.8 & 1.7 & 1.7 & 1.8 & 1.9 & 1.9 & 2.0 & 2.3 & 1.6 & 2.9 \\
\hline \multicolumn{11}{|l|}{ Management } \\
\hline Administrative expenses to total assets & 4.8 & 4.6 & 4.5 & 4.4 & 4.3 & 4.3 & 4.2 & 4.6 & 3.6 & 4.2 \\
\hline Noninterest expenses to gross income & 77.2 & 79.6 & 82.2 & 79.3 & 78.9 & 77.4 & 75.7 & 76.7 & 83.3 & 37.0 \\
\hline Total expenses to total revenues & 90.6 & 91.0 & 91.7 & 92.5 & 93.0 & 93.5 & 93.7 & 93.8 & 96.0 & 90.3 \\
\hline \multicolumn{11}{|l|}{ Profitability } \\
\hline Return on assets (ROA) & 1.5 & 1.6 & 1.7 & 1.8 & 1.7 & 1.6 & 1.5 & 1.3 & 1.2 & 1.8 \\
\hline Return on equity (ROE) & 11.8 & 12.2 & 13.4 & 14.3 & 14.3 & 12.4 & 11.5 & 11.6 & 12.7 & 9.5 \\
\hline Interest margin to gross income & 34.0 & 29.4 & 25.6 & 20.8 & 20.4 & 20.8 & 21.7 & 25.0 & 13.4 & 34.5 \\
\hline \multicolumn{11}{|l|}{ Liquidity } \\
\hline Liquid assets to total short-term liabilities & 87.5 & 84.6 & 80.1 & 83.0 & 94.9 & 101.2 & 99.6 & 88.7 & 91.2 & 574.7 \\
\hline Liquid assets to total assets & 32.5 & 29.7 & 27.4 & 27.7 & 30.0 & 31.1 & 30.7 & 36.0 & 25.1 & 24.2 \\
\hline Loans to deposits & 103.1 & 107.3 & 109.8 & 109.7 & 101.9 & 98.6 & 98.4 & 79.1 & 118.6 & 151.0 \\
\hline Liquid assets to deposits & 48.5 & 44.6 & 41.0 & 42.1 & 43.7 & 44.8 & 43.7 & 46.4 & 37.0 & 49.9 \\
\hline \multicolumn{11}{|l|}{ Sensitivity to market risk } \\
\hline Net open FX position to capital & 19.0 & 21.7 & 19.5 & 20.4 & 22.8 & 22.9 & 26.4 & 11.7 & 77.2 & 1.1 \\
\hline \multicolumn{11}{|l|}{ Other } \\
\hline Financial margin $1 /$ & 7.8 & 7.6 & 7.7 & 7.9 & 8.0 & 8.3 & 7.9 & 8.4 & 4.9 & 7.4 \\
\hline Credit growth (over a year ago) & 38.3 & 40.0 & 33.5 & 27.8 & 20.6 & 13.1 & 10.4 & 9.8 & 14.8 & 3.6 \\
\hline Deposit growth (over a year ago) & 22.4 & 23.8 & 21.3 & 25.4 & 21.9 & 23.1 & 24.6 & 19.4 & 42.7 & 19.6 \\
\hline
\end{tabular}

Source: Superintendency of Banks.

$1 /$ Difference between implicit loan and deposit rates. 


\section{Letter of Intent}

Attachment 1

San José, November 18, 2009

Mr. Dominique Strauss-Kahn

Managing Director

International Monetary Fund

Washington, D.C.

Dear Mr. Strauss-Kahn:

1. The purpose of this letter is to inform you about the progress in the implementation of our economic program, which is being supported under the Stand-By Arrangement (SBA) approved by the IMF Executive Board on April 10, 2009. The attached supplement to the Memorandum of Economic and Financial Policies (MEFP) summarizes developments since the completion of the first program review on September 23, 2009, and describes modifications to the program.

2. Macroeconomic developments have been broadly in line with projections made at the time of the first program review. The decline in real GDP moderated in the second quarter of 2009, mainly reflecting a recovery in the manufacturing sector. Inflation fell to 4 percent in October, and inflation expectations are gradually approaching the central bank's inflation target range for 2010. The external current account deficit is likely to be smaller than projected, and in the past two months the colón has traded continuously below the ceiling of the currency band. Liquidity and solvency indicators of the banking sector remain adequate.

3. Performance against the program targets remains very strong. All quantitative performance criteria for end-September were met, most with significant margins. Work is underway toward the implementation of the two end-December structural benchmarks (submission of draft laws to create a deposit insurance scheme and strengthen the bank resolution framework).

4. In light of this performance and our continued commitment to the program, we request completion of the second review under the SBA. Our intention remains to treat the arrangement as precautionary. We are requesting to change the frequency of program reviews from quarterly to biannual, given reduced uncertainty about the external environment and lower program risks, and bring forward the availability date of the fourth purchase under the arrangement. The third and final program review would be expected to take place in late June 2010. The program's quantitative performance criteria and indicative targets for end-December 2009 and endMarch 2010, and remaining structural benchmarks are set out in Tables 1 and 2 of the attached supplement to the MEFP. 
5. We believe that the policies described in the attached supplement to the MEFP are adequate to meet the objectives of our program. However, if needed, the government stands ready to take additional measures. In accordance with the Fund's policies, we will be in continuous communication with the Fund with regard to policy actions related to this program.

Sincerely yours,

/s/

Jenny Phillips

Minister of Finance /s/

Francisco de Paula Gutiérrez

President, Central Bank of Costa Rica

Attachments 
Attachment 2

\section{Supplement to the Memorandum of Economic and Financial Policies}

\section{November 18, 2009}

1. Recent developments. Macroeconomic developments have been broadly in line with projections made at the time of the first program review. The decline in real GDP moderated in the second quarter of 2009 (to -2.4 percent $y / y$, from -4.5 percent in the first quarter), mainly reflecting a recovery in the manufacturing sector. Moreover, in September the indicator of economic activity rose 0.3 percent from the previous month (seasonally adjusted), marking the seventh consecutive month of positive growth. In October, headline and core inflation fell further, to 4.0 and 5.7 percent $(\mathrm{y} / \mathrm{y})$ respectively, while median 12-month inflation expectations declined to 7.3 percent, gradually approaching to the central bank (BCCR)'s inflation target range of 4-6 percent for end-2010. In the first half of 2009, the external current account was broadly in balance, whereas the capital account posted a modest surplus ( 0.4 percent of GDP), despite a significant slowdown in FDI. In the third quarter, exports showed signs of recovery while import growth remained subdued. As a result, the trade deficit through September was substantially lower than during the same period last year. In addition, the colón has traded continuously below the ceiling of the currency band since mid-August. In the banking sector, the aggregate nonperforming loan ratio and the capital adequacy ratio deteriorated slightly, but liquidity and solvency indicators remained adequate.

2. Performance under the program. All quantitative performance criteria for endSeptember were met, most of them with significant margins. Base money growth at endSeptember was somewhat above program projections, reflecting a temporary spike in commercial bank deposits at the BCCR that reversed during October.

3. Macroeconomic framework. The outlook for 2009 and 2010 remains broadly unchanged from the first program review. The macroeconomic framework assumes a gradual recovery with real GDP growth of around 2.5 percent in 2010, following a 1-1.5 percent contraction in 2009. Inflation is on track to fall to 5 percent (12-month basis) by end-2009, and is expected to remain within the central bank's target band of 4-6 percent in 2010. The external current account deficit is now expected to be somewhat smaller than previously projected at 3.0 percent and 4.5 percent of GDP in 2009 and 2010, respectively.

4. $\quad$ Fiscal policy. Central government revenues through September were 7.7 percent lower than during the same period of 2008, mainly owing to a sharp drop in import-related taxes (including sales and excise taxes collected at customs). This performance was somewhat weaker than assumed in the program, and revenues for the whole year 2009 could fall short of program projections by about 0.3 percent of GDP. At the same time, central government spending has been lower than projected, and we expect some underexecution to persist through the end of the year. As a result, we are keeping the program target for the overall central government deficit 
in 2009 unchanged at 4.1 percent of GDP. The deficit target for 2010 of 4.1 percent of GDP also remains unchanged, although with lower estimates for both revenues and expenditures in light of the anticipated underperformance in 2009. Our quarterly fiscal program for 2010 envisages a gradual withdrawal of fiscal stimulus. The program allows for a small positive fiscal impulse during the first half of the year, to provide continued support to domestic demand until the recovery of the private sector strengthens.

5. Monetary and exchange rate policies. The downward trend of core inflation and inflation expectations, and the persistence of a negative output gap suggest that the inflation target for 2010 (4-6 percent) is achievable. However, there are some upside risks to the outlook as the dampening effect of the fall in commodity prices of early 2009 will unwind, and depreciation expectations and nontradables inflation remain above the target range. In view of these risks, the BCCR will continue to maintain a cautious approach to monetary policy easing. Our exchange rate policy will remain guided by the objective of gradually achieving greater flexibility of the colón.

6. Safeguards assessment. The recommendations of the safeguard assessment of the BCCR that was completed in July 2009 are being implemented. In particular, the BCCR has appointed an external auditor to conduct annual audits of the BCCR financial statements from 2008 onwards. The scope of the audit includes an analysis of the existing gaps between the BCCR's accounting practices and IFRS, in order to establish an action plan for the implementation of IFRS by 2011.

7. Program monitoring. The program will continue to be monitored on a quarterly basis, by quantitative performance criteria, indicative targets, and structural benchmarks. We are requesting to change the frequency of program reviews from quarterly to biannual, given reduced uncertainty about the external environment and lower program risks. The next and final program review is therefore expected to take place in June 2010. The quantitative performance criteria and indicative targets for end-December 2009 and end-March 2010 are set out in Table 1. The structural benchmarks of the program and the phasing of access under the arrangement are set out in Tables 2 and 3, respectively. 
Table 1. Costa Rica: Quantitative Performance Measures

(In billion of colones, unless otherwise indicated)

\begin{tabular}{|c|c|c|c|c|c|c|c|c|c|}
\hline & \multicolumn{8}{|c|}{2009 Program } & \multirow{3}{*}{$\frac{2010 \text { Program }}{\frac{\text { End-March 2/ }}{\text { Proposed }}}$} \\
\hline & \multicolumn{2}{|c|}{ End-March 1/ } & \multicolumn{2}{|c|}{ End-June } & \multicolumn{2}{|c|}{ End-September } & \multicolumn{2}{|c|}{ End-December } & \\
\hline & Prog. 3/ & Actual & Prog. 3/ & Actual & Prog. 4/ & Actual & Prog. 4/ & $\overline{p o s e d}$ & \\
\hline \multicolumn{10}{|l|}{ Quantitative Performance Criteria } \\
\hline Floor on cash balance of the Central Government (cumulative) & -210 & -106 & -312 & -206 & -471 & -377 & -639 & -639 & -322 \\
\hline Ceiling on the debt stock of the Central Government & 4,303 & 4,239 & 4,356 & 4,338 & 4,753 & 4,551 & 4,871 & 4,914 & 5,286 \\
\hline Ceiling on NDA of the Central Bank 5/ & -915 & $-1,301$ & -786 & $-1,244$ & -970 & $-1,170$ & -896 & -896 & -800 \\
\hline Floor on NIR of the Central Bank (million of US\$) 5 / & 3,500 & 4,167 & 3,350 & 3,936 & 3,555 & 4,059 & 3,705 & 3,705 & 3,405 \\
\hline \multicolumn{10}{|l|}{ Continuous Performance Criteria } \\
\hline Accumulation of external debt arrears & 0 & 0 & 0 & 0 & & 0 & & 0 & 0 \\
\hline \multicolumn{10}{|l|}{ Indicative targets } \\
\hline Floor on cash balance of the combined public sector (cumulative) & -146 & -43 & -325 & -179 & -524 & -411 & -774 & -774 & -352 \\
\hline \multicolumn{10}{|l|}{ Memorandum item } \\
\hline Base money & 1,102 & 1,101 & 1,144 & 1,024 & 1,079 & 1,170 & 1,240 & 1,240 & 1,163 \\
\hline Program exchange rate (ask price, colones per U.S. dollar) & 576 & 558 & 576 & 569 & 576 & 576 & 576 & 576 & 576 \\
\hline
\end{tabular}

Sources: Central Bank of Costa Rica; Ministry of Finance; and Fund staff projections.

1/Projection only. Performance criteria were only set from end-June onward.

2/ The end-March 2010 quantitative PCs will be evaluated at the 2009 program exchange rates as defined in the TMU for the first review (IMF Country Report No. 09/303).

3/ IMF Country Report No. 09/134.

4/ IMF Country Report No. 09/303.

5/ The floor on NIR and ceiling on NDA at end-September and end-December have been adjusted by $\$ 205$ million compared to the levels set at program approval (IMF Country Report No. 09/134) to reflect the special and general SDRs allocations of 132.81 millions SDRs. 
Table 2. Structural Benchmarks

\begin{tabular}{lll}
\hline & Test Date & Status \\
\hline $\begin{array}{l}\text { Establishment of a monthly monitoring report for } \\
\text { the banking system. }\end{array}$ & End-June 2009 & Met \\
$\begin{array}{l}\text { Unification of the money market under a single } \\
\text { platform. }\end{array}$ & End-June 2009 & Met (by August 2009) \\
$\begin{array}{l}\text { Establishment of a system of daily forecasting of } \\
\text { systemic liquidity in the money market. }\end{array}$ & End-June 2009 & Met \\
$\begin{array}{l}\text { Submission to parliament of a draft law to } \\
\text { strengthen the bank resolution framework. }\end{array}$ & End-December 2009 & \\
$\begin{array}{l}\text { Submission to parliament of a draft law to create a } \\
\text { limited deposit guarantee scheme. }\end{array}$ & End-December 2009 \\
\hline
\end{tabular}

Table 3. Schedule of Availability of Disbursements

\begin{tabular}{lll}
\hline Amount & Date & Conditions for Disbursement \\
\hline SDR 328,200,000 & $\begin{array}{l}\text { April 10, } \\
2009\end{array}$ & $\begin{array}{l}\text { Executive Board approval of the 18-month Stand-By } \\
\text { Arrangement. }\end{array}$ \\
SDR 41,025,000 & $\begin{array}{l}\text { September 23, } \\
2009\end{array}$ & $\begin{array}{l}\text { Observance of performance criteria for end-June } 2009 \text { and } \\
\text { completion of the first review under the Stand-By Arrangement. }\end{array}$ \\
SDR 41,025,000 & $\begin{array}{l}\text { December 16, } \\
2009\end{array}$ & $\begin{array}{l}\text { Observance of performance criteria for } \\
\text { end-September 2009 and completion of the second review } \\
\text { under the Stand-By Arrangement. }\end{array}$ \\
SDR 41,025,000 & $\begin{array}{l}\text { January 29, } \\
2010\end{array}$ & $\begin{array}{l}\text { Observance of performance criteria for end-December } 2009 . \\
\text { June 17, } \\
2010\end{array}$
\end{tabular}


Press Release No. 09/470

International Monetary Fund

FOR IMMEDIATE RELEASE

Washington, D.C. 20431 USA

December 18, 2009

\section{IMF Executive Board Completes Second Review Under Stand-By Arrangement with Costa Rica}

The Executive Board of the International Monetary Fund (IMF) completed on December 16, 2009 the second review of Costa Rica's economic performance under a program supported by a 15-month Stand-By Arrangement (SBA). The authorities have indicated that they will continue treating the arrangement as precautionary.

The SBA was approved on April 13, 2009 (See Press Release No. 09/124) for SDR 492.3 million (about US\$783.5 million) Completion of the review makes an additional SDR 41.025 million (about US\$65.3 million) available for disbursement, bringing the total resources that are currently available to Costa Rica under the arrangement to SDR410.25 million (about US\$652.9 million).

Following the Executive Board's discussion on Costa Rica, Mr. Murilo Portugal, Deputy Managing Director and Acting Chair, stated:

"Costa Rica's performance under the Stand-By arrangement with the Fund is commendable. An economic recovery is gradually taking hold, inflation has moderated to a historically low level, and the financial sector has remained sound. The authorities' economic program has helped cushion the impact of the global downturn and is providing a solid framework to support the recovery. Economic policies will continue to strike a balance between supporting domestic demand in the near term and maintaining domestic and external stability to foster sustained growth over the medium term.

"Fiscal policy has provided timely support to domestic demand in 2009, and the fiscal program for 2010 allows room for some additional stimulus in the early part of the year. Afterwards, the authorities plan to gradually unwind the fiscal stimulus as the recovery of private demand takes hold.

"Inflation has continued to decline and the exchange rate has moved toward the middle of the currency band. These developments have increased the central bank's room for policy maneuver, although upside risks to the inflation outlook warrant maintaining a cautious 
approach to monetary easing. The more benign domestic and global environment also provides an opportunity to further modernize exchange rate and monetary operations, and advance in the transition toward inflation targeting.

"The banking sector has weathered the cyclical downturn well, and liquidity and solvency indicators remain adequate. Further progress in the reform agenda remains important to strengthen the financial sector safety net, including the recapitalization of the central bank and passage of legislation to enable consolidated financial sector supervision," Mr. Portugal said. 


\section{Statement by Ramon Guzman, Executive Director for Costa Rica and Johny Gramajo-Marroquin, Senior Advisor \\ December 16, 2009}

We thank Staff for a comprehensive and well-written paper. Our authorities broadly agree with the Staff's assessment. Performance under the Program was very strong; all quantitative performance criteria for end-September were meet, most with significant margins. Work is underway to accomplish the two structural benchmarks for December: a) submission of draft laws to create a deposit insurance scheme, and b) strengthening of the bank resolution framework.

Recent developments. Macroeconomic events have been largely consistent with estimations made on occasion of the first program review. The economy has been recovering gradually. As a matter of fact, the decline in real GDP in the fist quarter of 2009 ( -4.5 percent $y / y)$ was less severe in the second quarter $(-2.4$ percent $y / y)$, mainly due to a recovery in the manufacturing sector. In September, the indicator of economic activity (IMAE) increased 0.3 percent from the previous month (seasonally adjusted), which constitutes the seventh consecutive monthly increase. In November, annual headline and core inflation fell further, to 2.57 percent and 4.15 percent respectively, while average 12 -month inflation expectations declined to 7.4 percent, gradually approaching to the central bank's inflation target range of 4-6 percent for end-2010. In the first half of 2009, the balance of payments current account was broadly in balance, while the capital account observed a modest surplus ( 0.4 percent of GDP) despite an important slowdown in FDI. In the third quarter, exports showed signs of recovery while import growth remained subdued. As a result, the trade deficit through September was substantially lower than during the same period last year.

Economic outlook. The outlook for the rest of 2009 and for 2010 remains mostly unchanged from the first program review. In terms of economic activity, the macroeconomic framework assumes a gradual recovery with real GDP growth of around 2.5 percent in 2010, following a $1-1.5$ percent contraction in 2009. Annual inflation is on track to fall to around 4 percent by end-2009, and is expected to be within the central bank's target band of 4-6 percent during 2010. The external current account deficit is now projected to be slightly smaller than previously projected at 3.0 percent and 4.5 percent of GDP in 2009 and 2010, respectively.

Fiscal policy. Central government revenues through September were 7.7 percent lower than during the same period in 2008 , mainly owing to a sharp drop in import-related taxes (including sales and excise taxes collected at customs). This performance was somewhat weaker than assumed in the program, and revenues for the whole year 2009 could fall short of program projections by about 0.3 percent of GDP. At the same time, central government spending has been lower than projected, and it is expected some under-execution to persist through the end of the year. As a result, authorities are keeping the program target for the overall central government deficit in 2009 unchanged at 4.1 percent of GDP. The deficit 
target for 2010 of 4.1 percent of GDP also remains unchanged, although with lower estimates for both revenues and expenditures in light of the anticipated underperformance in 2009. Authorities will continue to strike an adequate balance between supporting domestic demand and keeping public debt dynamics manageable. In that context, the quarterly fiscal program for 2010 envisages a gradual withdrawal of fiscal stimulus, however allowing a small positive fiscal impulse during the first half of the year in order to provide continued support to domestic demand until recovery of the private sector strengthens.

Our authorities believe that given the global economic reality, the exchange of information between nations is fundamental for the optimal application of tax systems, taking into account the current international practices.

Monetary policy. The descending trend of core inflation and inflation expectations, and the persistence of a negative output gap suggest that the inflation target for 2010 (4-6 percent) is feasible under the current monetary policy stance. Although there are some upside risks to the outlook related to the dampening effect of the fall in commodity prices of early 2009 that is expected not to come again, the Central Bank will continue to maintain a prudent approach to monetary policy easing.

Exchange rate policy. The colón has traded continuously below the ceiling of the currency band since mid-August. The authorities consider that this situation, along with the decline in inflation, provide some room for more flexibility in the exchange rate. Therefore, the exchange rate policy will remain guided by the objective of gradually increasing the flexibility of the colón.

Banking sector. In the banking sector, the aggregate nonperforming loan ratio and the capital adequacy ratio deteriorated slightly; however, liquidity and solvency indicators remained adequate.

Finally, the authorities believe that the ongoing policies are adequate to meet the objectives of their economic program, which has been effectively supported by the Stand-By arrangement. The authorities reiterate that they will continue treating the arrangement as precautionary. 